\title{
Combined hazard of typhoon-generated meteorological tsunamis and storm surges along the coast of Japan
}

\author{
Mohammad Heidarzadeh $^{1}$ (D) . Alexander B. Rabinovich ${ }^{2,3}$
}

Received: 2 July 2020 / Accepted: 23 November 2020 / Published online: 7 December 2020

(c) The Author(s) 2020

\begin{abstract}
Two hazardous typhoons, Lionrock (August 2016) and Jebi (September 2018), destructively affected the coast of Japan and produced extreme sea level variations. The results of field surveys in the impacted regions showed that multiple deaths and extensive floods were caused by the combined effect of low-frequency sea level raise (storm surges) and intensive high-frequency (HF) tsunami-like waves (meteotsunamis). The data from ten tide gauges for the 2016 event and eight gauges for the 2018 event were used to examine the properties of the observed sea levels, to estimate the relative contribution of the two sea level components and to evaluate their statistical characteristics (maximum wave heights, amplitudes and periods of individual components, etc.). For the 2016 event, we found that the surge heights were from 12 to $35 \mathrm{~cm}$ and that the mean contribution of surges into the total observed sea level heights was $\sim 39 \%$; the meteotsunami amplitudes were from 22 to $92 \mathrm{~cm}$, and they contributed $61 \%$ of the total height. For the 2018 event, storm surges were significantly stronger, from 46 to $170 \mathrm{~cm}$, while HF amplitudes were from 38 to $130 \mathrm{~cm}$; their relative inputs were $67 \%$ and $33 \%$, respectively. Combined, they formed total flood heights of up to $120 \mathrm{~cm}$ (2016 event) and $288 \mathrm{~cm}$ (2018 event). Previously, the contribution of storm seiches (meteotsunamis) in coastal floods had been underestimated, but results of the present study demonstrate that they can play the principal role. What is even more important, they produce devastating currents: according to our estimates, current speeds were up to 3 knots $(1.5 \mathrm{~m} / \mathrm{s})$ during the Lionrock event and more than 5 knots $(2.6 \mathrm{~m} / \mathrm{s})$ during Jebi; these strong currents appear to be the main reason for the resulting damage of coastal infrastructure. The most important characteristic of the recorded meteotsunamis is their trough-to-crest maximum height. During the 2016 event, these heights at three stations were $>1 \mathrm{~m}: 171 \mathrm{~cm}$ at Erimo, $109 \mathrm{~cm}$ at Hachijojima and $102 \mathrm{~cm}$ at Ayukawa. The 2018 event was stronger; maximum meteotsunami wave heights were $257 \mathrm{~cm}$ at Gobo, $138 \mathrm{~cm}$ at Kushimoto, $137 \mathrm{~cm}$ at Kumano and $128 \mathrm{~cm}$ at Murotomisaki. The 2018 Gobo height of $257 \mathrm{~cm}$ is much larger than historical non-seismic seiche maxima for the Pacific coast of Japan (140-169 cm) estimated by Nakano and Unoki (1962) for the period of 1930-1956.
\end{abstract}

Keywords Meteotsunami $\cdot$ Storm surge $\cdot$ Typhoon $\cdot$ Tide gauge records $\cdot$ Seiches $\cdot$ Harbour oscillations $\cdot$ Statistics $\cdot$ Tsunami currents 


\section{Introduction}

Meteorological tsunamis (meteotsunamis) are strong tsunami-like ocean waves generated by atmospheric processes. They have approximately the same periods and spatial scales as ordinary tsunami waves and can affect coastal areas in a similar destructive way (cf. Monserrat et al. 2006; Vilibić et al. 2014). In recent years, meteotsunamis have attracted significant attention from scientists and specialists. A number of devastating meteotsunami events occurred in various parts of world oceans, including the coasts of North and South America, SE Asia, South Africa and Australia, as well as the Great Lakes (Pattiaratchi and Wijeratne 2015; Rabinovich 2020). The 3.5-m Dayyer meteotsunami of 19 March 2017 killed five people and severely destructed local infrastructure on the coast of the Persian Gulf (Salaree et al. 2018; Heidarzadeh et al. 2020a). In bays, inlets, harbours and lakes, meteotsunamis, as well as seismically generated tsunamis, have the same character of eigen oscillations of the corresponding basins, i.e. "extreme seiches" (Rabinovich 2009, 2020).

Various types of atmospheric disturbances can produce meteotsunamis. In general, all meteotsunamis may be divided into two principal groups: "good-weather" and "badweather" (Rabinovich 2020). The events of the first group are mostly generated by smallscale air-pressure disturbances, or by propagating atmospheric gravity waves (cf. Monserrat et al. 1991; Monserrat and Thorpe 1996); the weather during the corresponding events is commonly reported as "nice" and "quiet". "Good-weather" meteotsunamis are very typical for the Mediterranean region (cf. Rabinovich and Monserrat 1996; Vilibić and Šepić 2009; Šepić et al. 2015). In contrast, "bad-weather" meteotsunamis are normally generated by incoming hurricanes, typhoons and deep cyclones and are associated with stormy weather conditions. Extreme storm seiches with trough-to-crest wave heights $>30-40 \mathrm{~cm}$ are generally identified as meteotsunamis (cf. Pattiaratchi and Wijeratne 2015; Olabarrieta et al. 2017; Dusek et al. 2019); they are common on the Atlantic coasts of the USA and western Europe, on the oceanic coast of Japan, and in the Great Lakes (de Jong et al. 2003; Šepić and Rabinovich 2014; Olabarrieta et al. 2017; Dusek et al. 2019; Tanaka 2019).

There are important differences between these two types of meteotsunami:

1. "Good-weather" meteotsunamis are typically local events. They have a resonant nature and normally occur in a specific bay/harbour or in a few neighbouring bays (cf. Vilibić and Šepić 2009). There are some "hot spots" in the world oceans, where such events take place regularly and achieve extreme heights: in particular, Ciutadella Harbour, Menorca Island, Spain (cf. Gomis et al. 1993; Rabinovich and Monserrat 1996); Vela Luka Bay, Korčula Island, Croatia (cf. Orlić et al. 2010; Vilibić et al. 2016); Nagasaki Bay, Japan (Honda et al. 1908; Hibiya and Kajiura 1982; Tanaka 2010).

2. Storm seiches caused by propagating hurricanes or typhoons are "Bad-weather meteotsunamis" and considered as large-scale events that can be observed along large segments of the mainland coastline, for example along the entire East Coast of USA (cf. Thomson et al. 2007; Pasquet et al. 2013; Dusek et al. 2019).

While good-weather meteotsunamis are individual hazardous events, "bad-weather" meteotsunamis often coincide with other dangerous types of long-wave oscillations, in particular, with storm surges (cf. Thomson et al. 2007; Roeber and Bricker 2015). The superposition of waves from these two natural phenomena strongly increases the damaging effect of this hazard. 
Typhoons are usually associated with a number of hazards in a cascading order, including severe storm waves, wind-blown debris, storm surges, extreme seiches, intensive rainfall, landslides and debris flows (cf. Heidarzadeh et al. 2018, 2020b). Among these hazards, the two common and coinciding ones are seiches (meteotsunamis) and storm surge. Both meteotsunamis and storm surges are atmospherically induced events. Therefore, for scientists and authorities working on hazard mitigation and coastal engineering, it appears to be difficult to distinguish the differences between these two phenomena (Rabinovich 2020). However, meteotsunamis and storm surges have quite dissimilar temporal and spatial scales and principally have different generation mechanisms. A storm surge is a lowfrequency process, with typical periods/durations from several hours to approximately one week; they can flood extensive coastal areas of several hundred kilometres (Pugh and Woodworth 2014). Meteotsunamis have the same periods and other properties as ordinary tsunami waves; in harbours and bays ("harbour meteotsunamis") they have a scale of the corresponding local basins and periods determined exactly by natural (eigen) periods of the basins. This means that their spatial scales are from a few hundred metres to a few tens of kilometres and their periods from 1 to 2 min to approximately two hours (Rabinovich 2020).

Storm surges are formed by the combined effect of low air pressure and wind, where the wind generally plays the determining role in producing destructive surges (cf. Pugh and Woodworth 2014). In contrast, meteotsunamis are mainly induced by direct air pressure forcing and are usually related to propagating atmospheric disturbances (Monserrat et al. 2006; Šepić et al. 2015). The principal differences between meteotsunamis and surges are discussed in detail by Rabinovich (2020). What is crucial, storm surges and seiches are typically combined together. During strong storms, normally associated with incoming hurricanes, typhoons and deep cyclones, background coastal seiches are considerably intensified and can be identified as "meteotsunamis" (cf. Olabarrieta et al. 2017; Dusek et al. 2019; Heidarzadeh et al. 2018). Such extreme storm seiches and associated reversing currents can lead to the breaking of mooring lines, fenders and piles and can seriously damage anchored boats (Rabinovich 2009). The damaging effect of storm surges is strongly amplified by their superposition with storm seiches/meteotsunamis (cf. Thomson et al. 2007); however, this effect is still underestimated or, at least, is poorly investigated. The main challenge for a combined examination is the very different temporal/spatial scales of these two phenomena; in particular, the sampling interval of $1 \mathrm{~h}$ for sea level data is good enough to operatively analyse storm surges (Pugh and Woodworth 2014), while for seiches/meteotsunamis the optimum sampling should be two orders finer (0.5-2.0 min) (Vilibić et al. 2016). Similarly, the numerical modelling of a storm surge can be effectively done based on a computational grid with 0.5 arc min resolution $(\sim 0.9 \mathrm{~km})$ (Pugh and Woodworth 2014), whereas to reproduce actual meteotsunami oscillations we need a $0.5-1.0$ arc sec grid $(15-30 \mathrm{~m})$ (Orlić et al. 2010; Rabinovich et al. 2020). That is why, there are only a few papers considering these two processes together (cf. Roeber and Bricker 2015; Bajo et al. 2019). In the present study, this exact effect, the combination of storm-generated meteotsunamis and storm surges, is examined for two devastating typhoons affecting the coast of Japan in 2016 and 2018.

Japan is the country most impacted by hazardous tsunami waves. At the same time, pronounced atmospherically induced tsunami-like seiches are also common in multiple bays and inlets of the Japanese coast (cf. Honda et al. 1908). Especially intense seiches, i.e. meteotsunamis, are generated by severe typhoons (with air pressure as low as 920-960 hPa), which destructively impact Japan in the summer and fall seasons. In fact, the term "meteorological tsunamis" originally came from Japan and was specifically related to 
ruinous tsunami-like waves produced by typhoons (Nomitsu 1935). Severe typhoons are characterized by very low air pressure and are frequently accompanied by sustained hurricane onshore winds. These two factors cause powerful surges on the oceanic coasts of Japan. At the same time, this extreme atmospheric forcing produces strong storm seiches superimposed on surges.

Heidarzadeh et al. (2020b) and Le et al. (2019) thoroughly examined the impacts of two recent catastrophic typhoons on the Pacific coast of Japan: the 2016 Lionrock and 2018 Jebi typhoons. The primary focuses of their studies were field surveys of the affected territories and numerical modelling of generated storm surges. The results of their studies showed that multiple deaths and extensive coastal floods were partly caused by intensive high-frequency tsunami-like waves observed at several sites. Here, we further expand those studies by extracting storm surge and seiche signals from tide gauge records, estimating the effect of their superposition and the potential risk to coastal communities.

\section{The August 2016 Typhoon Lionrock}

Typhoon Lionrock was a destructive powerful tropical cyclone that on 25-31 August 2016 strongly affected the coasts of the Philippines, Japan, North Korea and Russia. The total damage in these four countries was estimated to be approximately US $\$ 4.0$ billion; the typhoon killed a total of about 550 people. The typhoon caused intense floods in coastal regions associated with extreme rainfalls, storm surges and seiches.

\subsection{Description of the event on the east coast of Japan}

The 2016 Typhoon Lionrock, also known as Typhoon No. 1610 in Japan (for being 10th in the 2016 typhoon season), was active in the Pacific Ocean region during the period of 16-31 August 2016. Lionrock made its main landfall on the coast of Japan on 30 August 2016 (Fig. 1) causing a series of hazardous effects, including severe flooding, hurricane winds and landslides; altogether 26 people were killed (FDMA 2017).

Lionrock was classified as a Category-5 hurricane in the Saffir-Simpson Hurricane Wind Scale (SSHWS) by reaching a maximum one-minute sustained wind speed of 60 $\mathrm{m} / \mathrm{s}$. As seen in Fig. 1, Lionrock travelled along a complicated track-it originated from the SE of Japan, moved towards the NW, then changed its direction to SW and after a full loop finally again began to propagate north-westward to make landfall in east Japan. The minimum typhoon pressure was $940 \mathrm{hPa}$ (Nayak and Takemi 2019). Approaching the coast of Japan, Lionrock began to slightly weaken; it made landfall near Ôfunato (Iwate Prefecture) on 30 August; maximum winds at that time were up to 70 knots $(35 \mathrm{~m} / \mathrm{s})$. As an example, Fig. 2a shows sea level pressure (SLP) records at Ofunato and nearby station Ishinomaki. Unfortunately, we did not have high-resolution air-pressure (AP) records at these or other Japanese stations that could probably uncover small-scale AP disturbances associated with this typhoon; normally such disturbances are the main source of meteotsunamis (cf. Monserrat et al. 2006; Rabinovich et al. 2020). Therefore, we used standard JMA ${ }^{1}$ AP measurements with 1-h sampling (Fig. 2a), which revealed the marked V-shape of the AP records during the typhoon passage over the respective

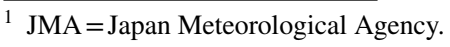




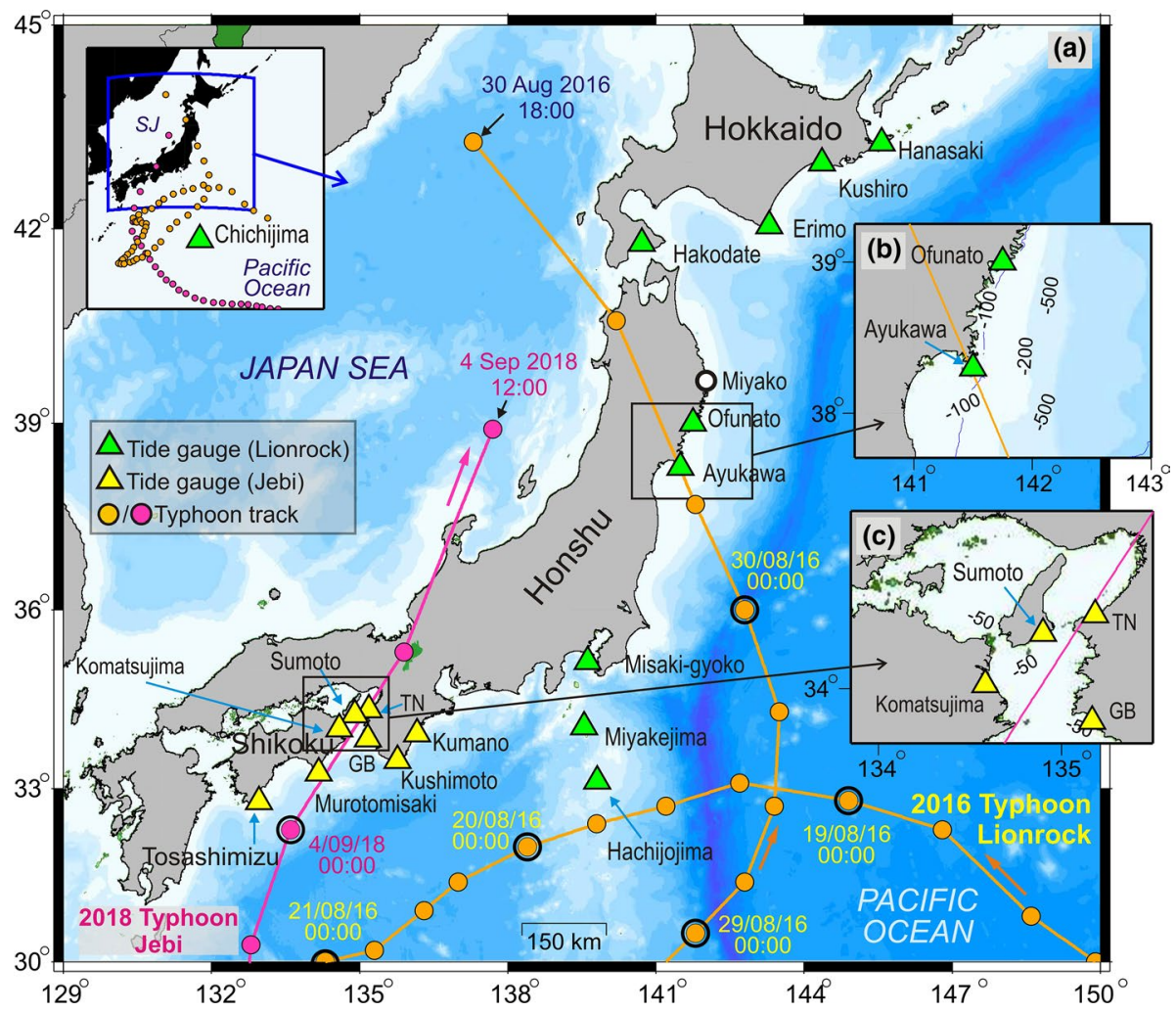

Fig. 1 a Tracks of the 2016 typhoon Lionrock (orange circles and line) and the 2018 typhoon Jebi (pink circles and line) and the locations of tide gauge stations used in this study. The circles show typhoon tracks with 6-h intervals. The circles with thick black edges mark the start of each day. Typhoon track data are from the Japan Meteorological Agency. $\mathbf{b}$ and $\mathbf{c}$ show the bathymetry of the coastal areas at the landfalls of typhoons Lionrock (2016) and Jebi (2018), respectively; water depths are in meters. Abbreviations: $\mathrm{GB}=\mathrm{Gobo} ; \mathrm{TN}=$ Tannowa. Station Chichijima is shown in the inset to $\mathbf{a}$

sites, with sharp SLP minima of $970 \mathrm{hPa}$ (Ofunato) and $972 \mathrm{hPa}$ (Ishinomaki) at 16:00 UTC on 30 August. A satellite image of the Lionrock typhoon (Fig. 2b) indicates that on 28 August 2016 the diameter of the Lionrock system was approximately $900 \mathrm{~km}$.

Field survey of the typhoon-affected areas was conducted in a few days after the event (Heidarzadeh et al. 2020b). Lionrock caused widespread damage through its various cascading effects as shown in Fig. 3. Typhoon-triggered severe flooding brought extensive mud into the city of Miyako (Fig. 3a; the location of Miyako is indicated in Fig. 1). In Ryouri Bay, a part of the caisson breakwater was damaged (Fig. 3b). An under-construction bridge in Miyako was partially damaged by extensive flood-driven debris (Fig. 3c), while wave-driven debris piled up at the coast of Miyako (Fig. 3d). The preliminary examination of the flooding and destruction demonstrated that they were associated with both long-period sea level rise and intensive short-period oscillations with periods from a few minutes to approximately 15-20 min (cf. FDMA 2017; Le et al 2019). Thus, the purpose of our further study was to examine both types of water motions. 

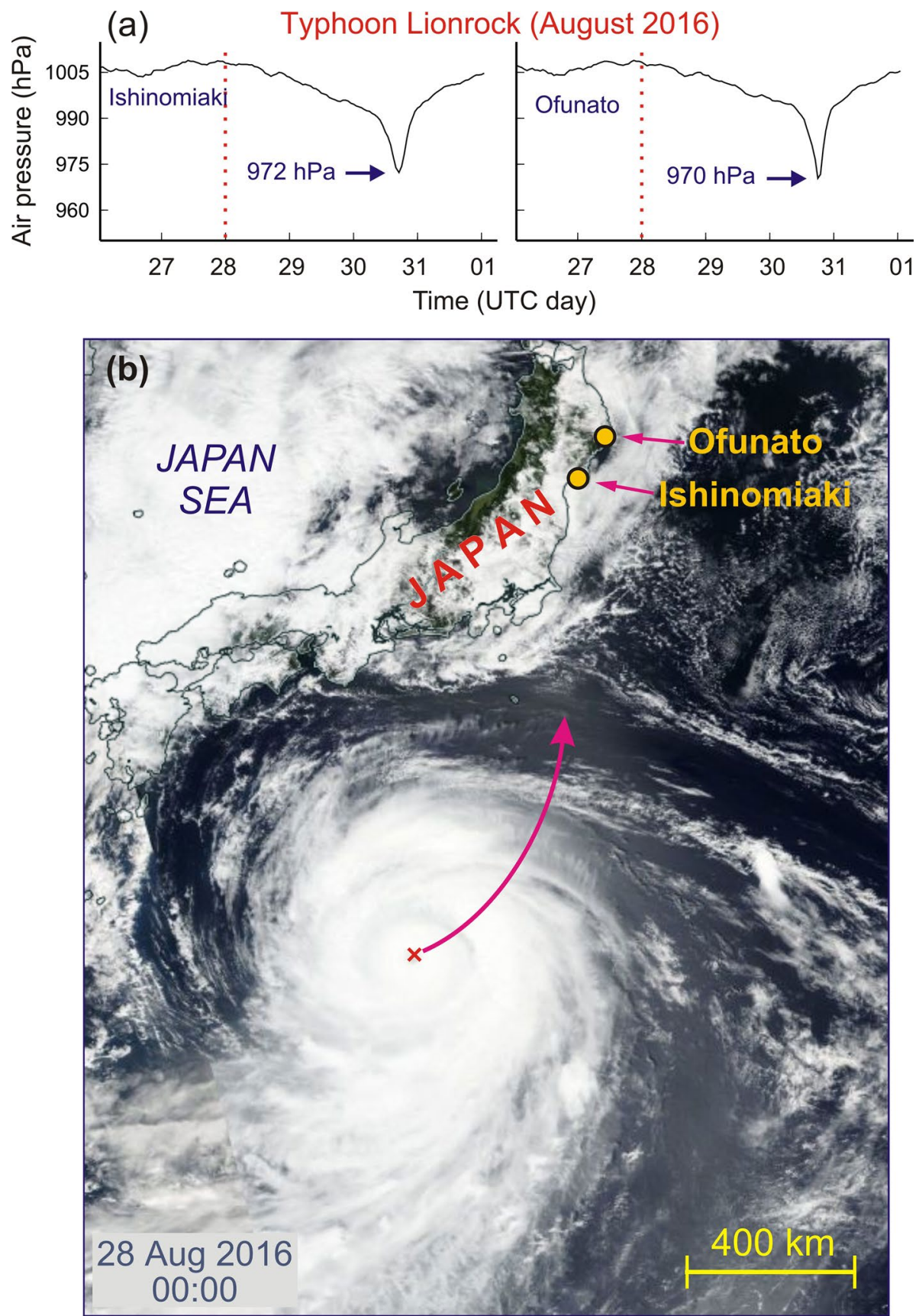

Fig. 2 a Pressure recordings at two locations along the coast of Japan during the 2016 typhoon Lionrock; the dashed vertical lines indicate the time of the satellite image. b A satellite image of the Typhoon Lionrock on 28 August 2016. The satellite image data are from the US National Aeronautics and Space Administration (NASA) earth dataset: https://worldview.earthdata.nasa.gov 
Damage made by 2016 Typhoon Lionrock in Japan
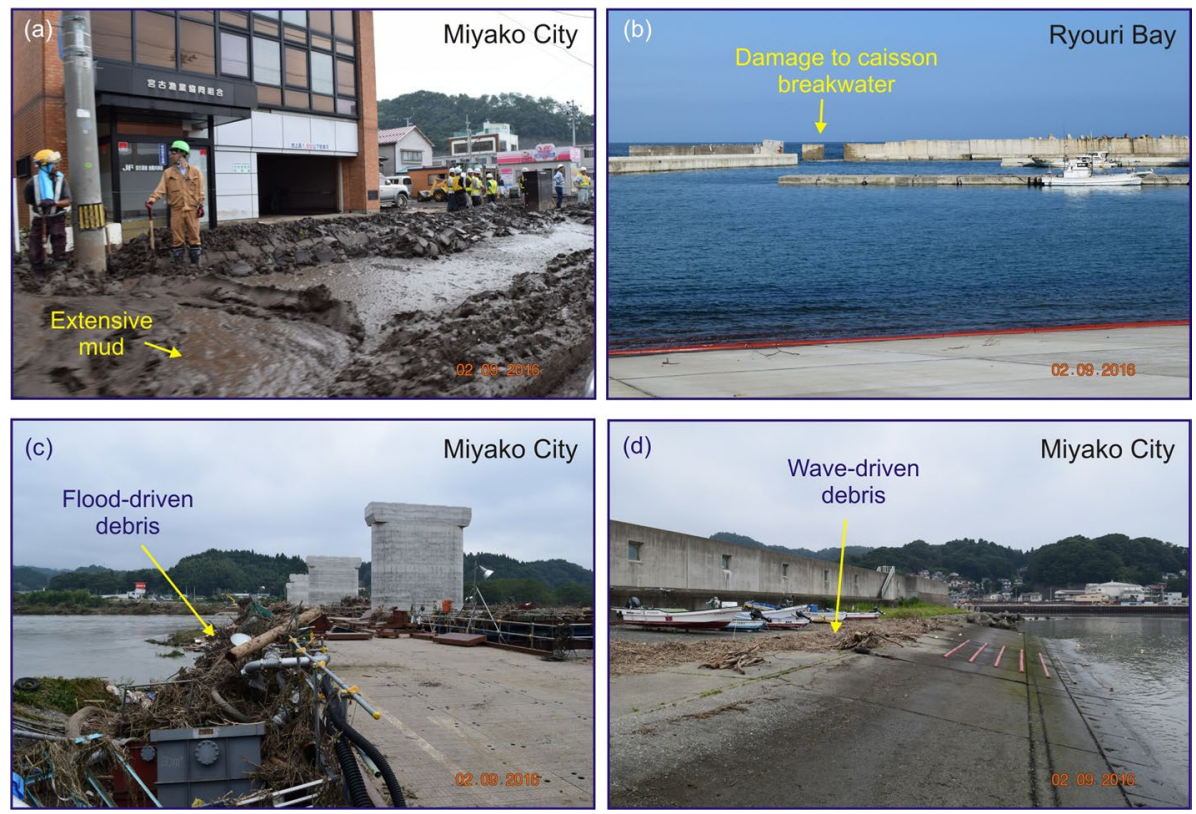

Fig. 3 Destructions made by typhoon Lionrock along the east coast of Japan in August-September 2016; Miyako City is indicated in Fig. 1, Ryouri Bay is located near Ofunato. Locations are: $141.9597^{\circ} \mathrm{E}$ and $39.6431^{\circ} \mathrm{N}$ for $\mathbf{a} ; 141.8136^{\circ} \mathrm{E}$ and $39.0563^{\circ} \mathrm{N}$ for $\mathbf{b} ; 141.9245^{\circ} \mathrm{E}$ and $39.6305^{\circ} \mathrm{N}$ for $\mathbf{c}$; the location $(\mathbf{d})$ is at a distance of a few hundred meters from location (c). Photographs belong to Mohammad Heidarzadeh

\subsection{The combined effect of storm surges and meteotsunamis}

Sea level oscillations caused by typhoon Lionrock were recorded by a great number of tide gauges. For our analysis, we selected ten stations: four on the east and south-east coast of Hokkaido Island, three on the east coast of Honshu Island and three located on isolated Pacific islands (Fig. 1). The data were provided by the Japan Meteorological Agency (JMA); all records had a sampling interval of $15 \mathrm{~s}$, except Ofunato which had 1-min sampling. The height resolution was $1 \mathrm{~cm}$, except Erimo, Misaki-gyoko and Hachijojima, which had a resolution of several $\mathrm{cm}$. The sea level data underwent quality control to remove gaps, spikes and outliers. The tides were calculated using the least-squares method (cf. Pugh and Woodworth 2014) and subtracted from the original records based on MATLAB T_Tide software (cf. Pawlowicz et al. 2002; Heidarzadeh et al. 2017); the resulting residual time series were used in all subsequent analyses.

As an example, Fig. 4a shows residual (de-tided) records at two stations: Kushiro and Ayukawa. The intensification of sea level variations during the typhoon passage is clearly seen in the records (Compare Fig. 4 with the Lionrock track shown in Fig. 1 and with AP records in Fig. 2a). At Ayukawa, the maximum variations were observed at about 15:00 UTC on 30 August 2016, at Kushiro approximately 9 h later. Two types of sea level changes are evident in the records: (1) low-frequency sea level rise with a duration of $\sim 2$ days and (2) high-frequency oscillations superimposed on the low-frequency rise. The first type of change is a storm surge (Pugh and Woodworth 2014), which appears to be 

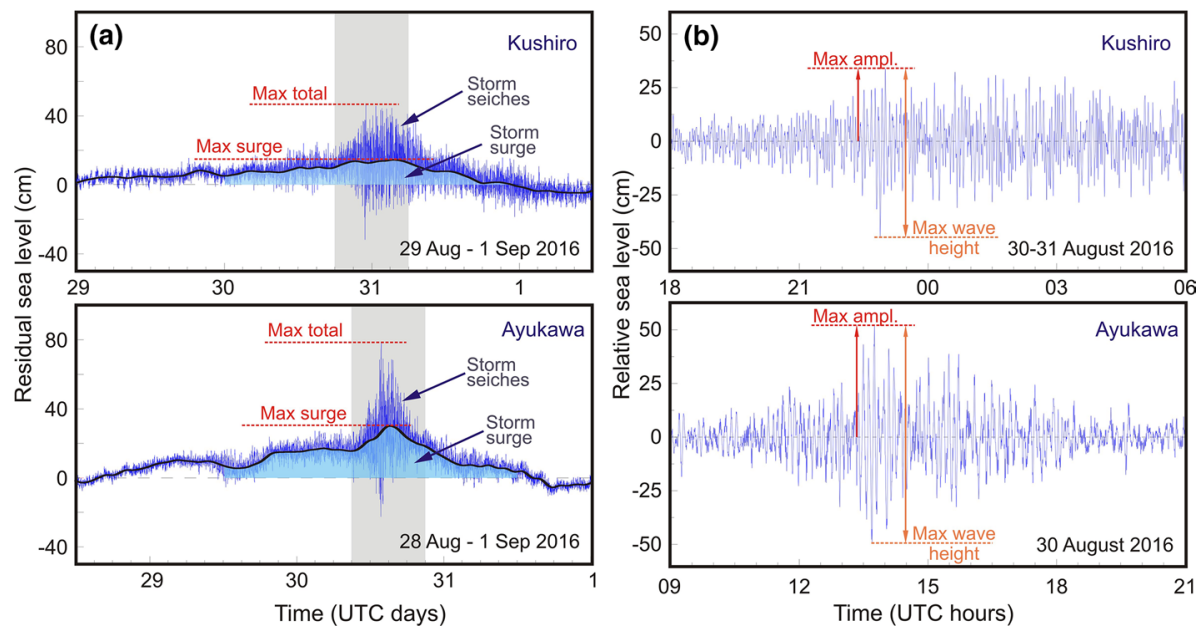

Fig. 4 Residual (de-tided) sea level records at stations Kushiro and Ayukawa on the east coast of Japan during passage of the 2016 Lionrock typhoon. a Partitioning of the records into low- and high-frequency oscillations using a 3-h Kaiser-Bessel window. The thick black lines denote the low-frequency components of the records; the shaded transparent region denotes the storm surge. The maximum observed (total) amplitude and the amplitude of the surge are indicated; and $\mathbf{b}$ expanded versions of the high-frequency (stormgenerated) seiches at the two stations for the record segments shaded grey in a. The maximum amplitudes and trough-to-crest wave heights are indicated

produced by the combined effect of very low air pressure and surge wind. The second type are storm seiches (Rabinovich 2009), which are so strong that they can be considered as meteotsunamis.

To separate these two types of sea level oscillations, we used a Kaiser-Bessel filter (cf. Thomson and Emery 2014) with a 3-h window. This window is commonly used to isolate tsunami waves and to separate storm surges and seiches (cf. Thomson et al. 2007; Rabinovich 2020). The black curve in Fig. 4a contours the storm surge that is also isolated by shading. Seiches (meteotsunamis) for the segments denoted in Fig. 4a by grey bands are shown in more detail in Fig. 4b. Both the storm surge and the storm seiches are atmospherically generated processes specifically related to the typhoon's passage, but as seen in Fig. 4, their character and the main features are in strong contrast. The storm surge at Kushiro and Ayukawa, as well as at other examined stations, for this event was not substantial, but combined with storm seiches it became hazardous.

\subsection{Observed sea level oscillations}

The de-tided unfiltered and filtered records were used to estimate the main parameters of the observed oscillations (Fig. 4):

- The total observed height above mean sea level (MSL), i.e. the height of the surge together with seiches.

- The surge height relative to MSL.

- The maximum seiche (meteotsunamis) amplitude relative to MSL.

- The observed dominant period of seiches. 
- The maximum trough-to-crest wave seiche (meteotsunami) height.

The latter parameter is important for meteotsunami research, since the maximum wave height is commonly used to identify and characterize meteotsunami events (cf. Rabinovich and Monserrat 1996; Pasquet et al. 2013; Dusek et al. 2019).

The parameters listed above have been estimated for all ten stations; the corresponding results are shown in Figs. 5 and 6 and presented in Table 1. The maximum observed (total) heights were from $33 \mathrm{~cm}$ (Hanasaki) to $120 \mathrm{~cm}$ (Erimo); the mean height (averaged over all 10 stations) was $66 \mathrm{~cm}$. The maximum surge heights were significantly smaller, $12-35 \mathrm{~cm}$, and the mean surge height was $25 \mathrm{~cm}$ (Fig. 5). The relatively amplified surge heights of $30-35 \mathrm{~cm}$ were at four stations located on the typhoon track (Ayukawa and Ofunato) or on the right-hand side of this track (Hakodate and Erimo); the smallest heights of 12-14 cm were at two northernmost stations, Hanasaki and Kushiro, and on the remote easternmost island Chichijima (see Fig. 1 for the station locations). The seiche amplitudes were considerably larger, from $22 \mathrm{~cm}$ (Hanasaki) to $92 \mathrm{~cm}$ (Erimo) (Fig. 6); the mean seiche amplitude was $\sim 44 \mathrm{~cm}$. The remarkable fact is that at nine from ten tide gauges, the seiche amplitudes were larger than the surge height; the only exception is Hakodate where the seiche amplitude of $26 \mathrm{~cm}$ was slightly smaller than the surge height of $35 \mathrm{~cm}$. The seiche amplitudes vary significantly from one station to another, strongly controlling the hazard level posed by the typhoon floods at each location. For instance, while both Erimo and Hakodate recorded the same surge height of $35 \mathrm{~cm}$ (Fig. 5), the maximum observed height at Erimo was $120 \mathrm{~cm}$, while at Hakodate it was only $57 \mathrm{~cm}$ because Erimo experienced much stronger seiching than Hakodate. It is noteworthy that Erimo was not located directly on the track of typhoon Lionrock, but was distanced approximately $300 \mathrm{~km}$ northward from the track (Fig. 1a). We can assume that Erimo is a "hot spot" (similar to Atlantic City on the US East Coast, cf. Šepić and Rabinovich 2014) and that some local topographic properties (e.g. the specific resonant properties of the adjacent shelf, funnelling effect of the coast, and high $Q$-factor of the respective inner basin) of this site promote strong sea level response to the propagating typhoon and fiercely amplified seiches. In general, the results of our analysis indicate that for typhoon Lionrock seiches were a greater hazard than the surge, while surges are commonly assumed to be the main reason for coastal floods when typhoons pass over the coast of Japan, or when hurricanes affect the US East Coast.

At all stations, the observed total heights were smaller than the sum of the maximum surge height and seiche amplitude (Table 1). The reason for this is the time lag between the occurrence of the corresponding maxima (Fig. 5). Nevertheless, in most cases the difference was less than 1-3 cm. At two stations, Erimo and Misaki-gyoko, the difference was $7 \mathrm{~cm}$, but the relative difference was rather small: $5.5 \%$ and $8.7 \%$, respectively. This means that the cumulative effect of the storm surge and seiches can roughly be counted as the sum of each of these phenomena. The data in Table 1 demonstrate that seiche heights at most stations were so large that they can be considered as meteotsunamis. In particular, at Erimo they were $171 \mathrm{~cm}$, which is comparable with the greatest meteotsunamis recorded during the last 27 years in various regions of the world oceans (Rabinovich 2020) At two other stations, Ayukawa and Hachijojima, they were higher than $1 \mathrm{~m}$ and at four more, Kushiro, Ofunato, Misaki-gyoko and Miyakejima, higher than $65 \mathrm{~cm}$. These heights are similar to those for the strongest hurricane-generated meteotsunamis on the coasts of the Gulf of Mexico and the East Coast of the USA (Olabarrieta et al. 2017; Dusek et al. 2019).

Based on visual analysis of the records themselves and on time-frequency (wavelet) analysis (see next section) we estimated the dominant periods of the recorded seiches were $45 \mathrm{~min}$ at Hakodate and 16 and $20 \mathrm{~min}$ at Hanasaki; at other stations, the observed seiche 
Lionrock typhoon of August 2016
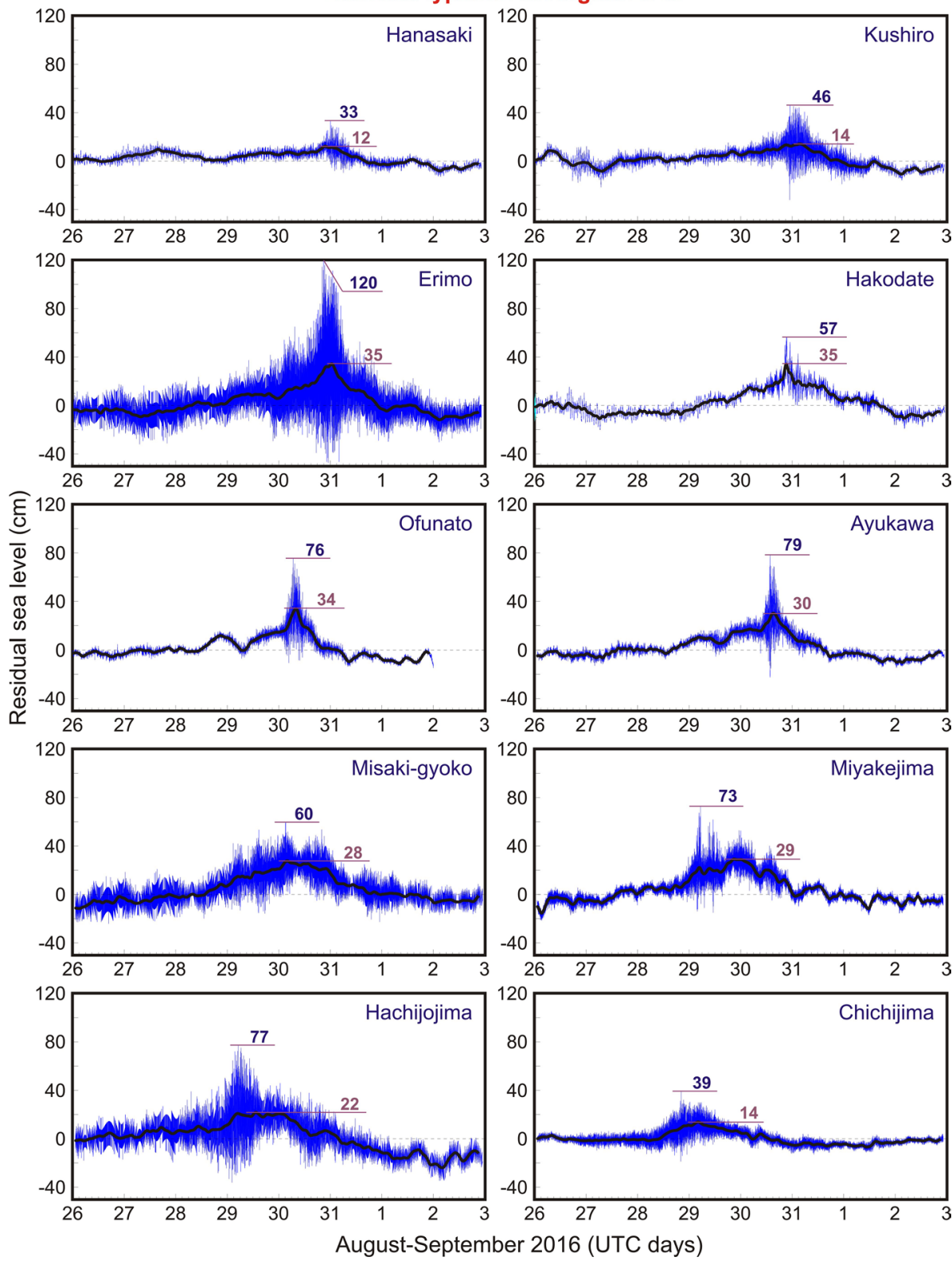

Fig. 5 Residual (de-tided) sea level records at ten stations on the coast of Japan during the 2016 typhoon Lionrock passage. The thick solid black curves show the low-frequency component of the records after lowpass filtering with a 3-h Kaiser-Bessel window. The blue and purple numbers are the maximum observed (total) amplitude and the surge height, respectively

periods were short, mostly shorter than 8 min (Table 1). These are shorter than typical periods of meteotsunamis (10-40 $\mathrm{min})$ associated with propagating small-scale atmospheric disturbances (Monserrat et al. 2006; Rabinovich 2020). High-frequency oscillations 
Lionrock typhoon of August 2016
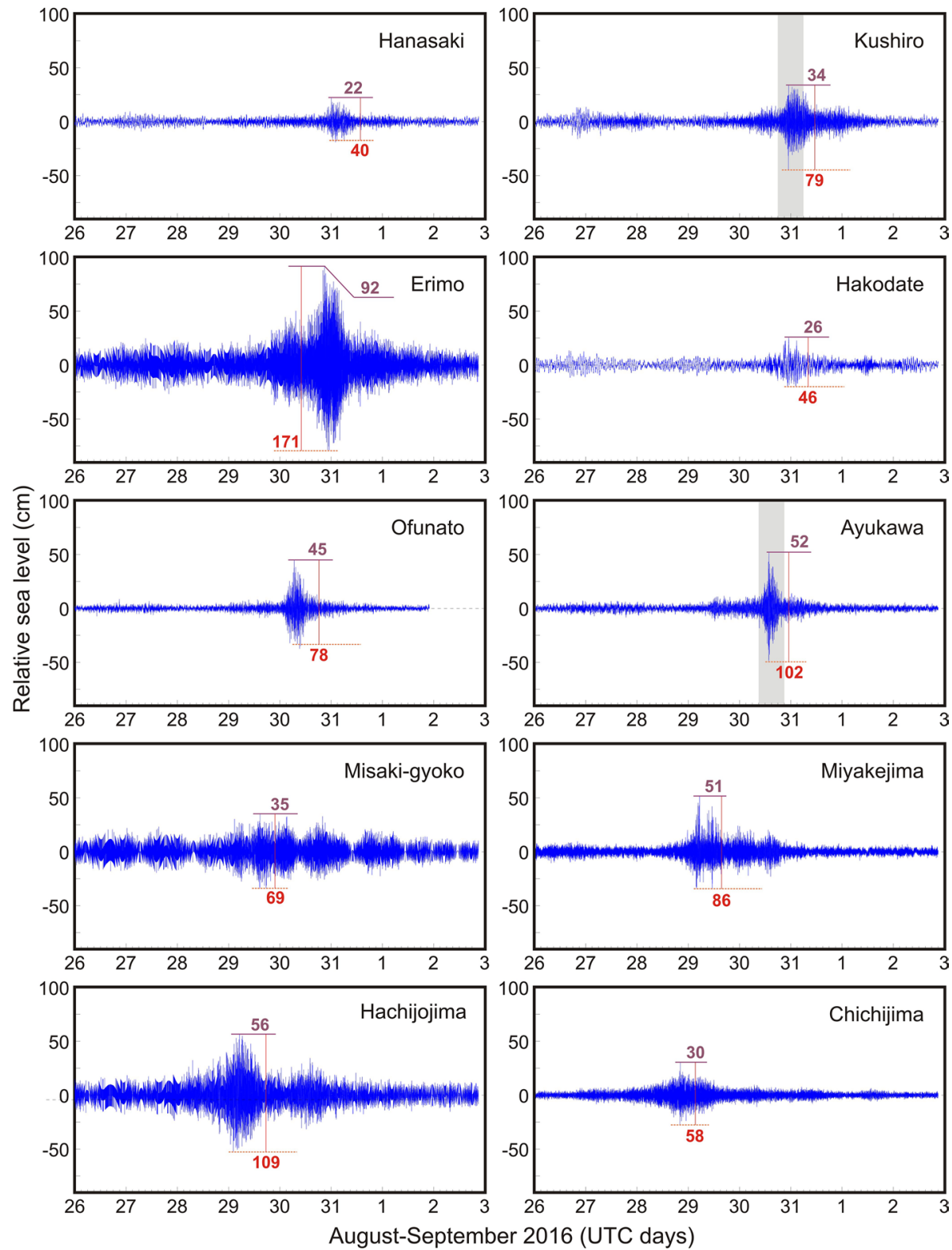

Fig. 6 The high-pass filtered (with a 3-h Kaiser-Bessel window) records of sea level oscillations at ten stations on the coast of Japan showing storm seiches (meteotsunamis) caused by the 2016 typhoon Lionrock. The purple and red numbers denote the maximum amplitudes and trough-to-crest wave heights, respectively

prevailing in the corresponding records can be explained by the strong influence of stormgenerated infragravity (IG) waves that have typical periods of 30-300 s (cf. Rabinovich 2009). 
Table 1 Locations of tide gauge stations and observed surge/seiche parameters of the corresponding records during the 2016 Typhoon Lionrock (Japan)

\begin{tabular}{|c|c|c|c|c|c|c|c|}
\hline \multirow[t]{2}{*}{ Station } & \multicolumn{2}{|c|}{ Coordinates } & \multirow{2}{*}{$\begin{array}{l}\text { Observed } \\
\text { (total) } \\
\text { height }(\mathrm{cm})\end{array}$} & \multirow{2}{*}{$\begin{array}{l}\text { Surge } \\
\text { height } \\
(\mathrm{cm})\end{array}$} & \multicolumn{3}{|c|}{ Seiches (meteotsunami) } \\
\hline & $\begin{array}{l}\text { Longitude } \\
\left({ }^{\circ} \mathrm{E}\right)\end{array}$ & $\begin{array}{l}\text { Latitude } \\
\left({ }^{\circ} \mathrm{N}\right)\end{array}$ & & & $\begin{array}{l}\text { Max } \\
\text { amplitude } \\
(\mathrm{cm})\end{array}$ & $\begin{array}{l}\text { Max height } \\
(\mathrm{cm})\end{array}$ & Period (min) \\
\hline Hanasaki & 145.567 & 43.283 & 33 & 12 & 22 & 40 & 16,20 \\
\hline Kushiro & 144.367 & 42.983 & 46 & 14 & 34 & 79 & $4,5,17$ \\
\hline Erimo & 143.294 & 42.043 & 120 & 35 & 92 & 171 & 5,10 \\
\hline Hakodate & 140.717 & 41.783 & 57 & 35 & 26 & 46 & 45 \\
\hline Ofunato & 141.750 & 39.000 & 76 & 34 & 45 & 78 & 4 \\
\hline Ayukawa & 141.500 & 38.300 & 79 & 30 & 52 & 102 & 7.5 \\
\hline $\begin{array}{r}\text { Misaki- } \\
\text { gyoko }\end{array}$ & 139.613 & 35.145 & 60 & 28 & 35 & 69 & 3,5 \\
\hline Miyakejima & 139.550 & 34.050 & 73 & 29 & 51 & 86 & 4 \\
\hline Hachijojima & 139.808 & 33.127 & 77 & 22 & 56 & 109 & $5-6$ \\
\hline Chichijima & 142.200 & 27.100 & 39 & 14 & 30 & 58 & $1,4,17$ \\
\hline
\end{tabular}

\subsection{Time-frequency analysis}

To examine temporal variations of the recorded seiche oscillations associated with the 2016 Lionrock typhoon in the frequency domain, we used a multiple-filter method, which is similar to wavelet analysis (cf. Thomson and Emery 2014; Thomson et al 2007; Heidarzadeh et al. 2020c, 2017) and is based on narrow-band filters with a Gaussian window that isolates a specific central frequency, $\omega_{n}=2 \pi f_{n}$, where $f_{n}$ is the frequency. This method has been effectively used previously to investigate various meteotsunami events (cf. Šepić and Rabinovich 2014; Šepić et al. 2015). The method enables us to determine the evolution of meteotsunami waves as a function of frequency, $f$, and time, $t$, and to build so called $f-t$ diagrams that display possible non-stationary character of the observed waves.

We selected four stations, Kushiro, Ayukawa, Miyakejima and Chichijima, and for these stations constructed the respective " $f-t$ diagrams" for the frequency band of 1-60 cph (cycles per hour), i.e. for the periods from $1 \mathrm{~h}$ to $1 \mathrm{~min}$. We used 3-day data segments: 29 August-1 September 2016 for the first two stations (the more northerly stations) and 28-31 August 2016 for the other two stations. The most prominent feature of the resulting plots, shown in Fig. 7, are well defined relatively narrow frequency bands of significantly amplified energy, which are likely associated with the eigen frequencies of the respective harbours. These "bands" in the $f-t$ diagrams approximately relate to the following periods: 4, 5 and $17 \mathrm{~min}$ at Kushiro; $7.5 \mathrm{~min}$ at Ayukawa; $4 \mathrm{~min}$ at Miyakejima; 1, 4 and $17 \mathrm{~min}$ at Chichijima. The same "bands" are clearly seen in background oscillations (before the typhoon arrival); however, during the event the respective oscillations strongly intensified. High-frequency stability and the persistent character of the corresponding "band" oscillations during the entire examined periods support the assumption of their resonant ("eigen") nature. For a few hours around the core time of the typhoon attack we can see dramatic amplification of these specific resonant oscillations and, at the same time, active generation of broad-band oscillations occupying almost the entire frequency band of 1-60 cph (Fig. 7). After the typhoon's passage, the broad-band oscillations decayed very fast, while 


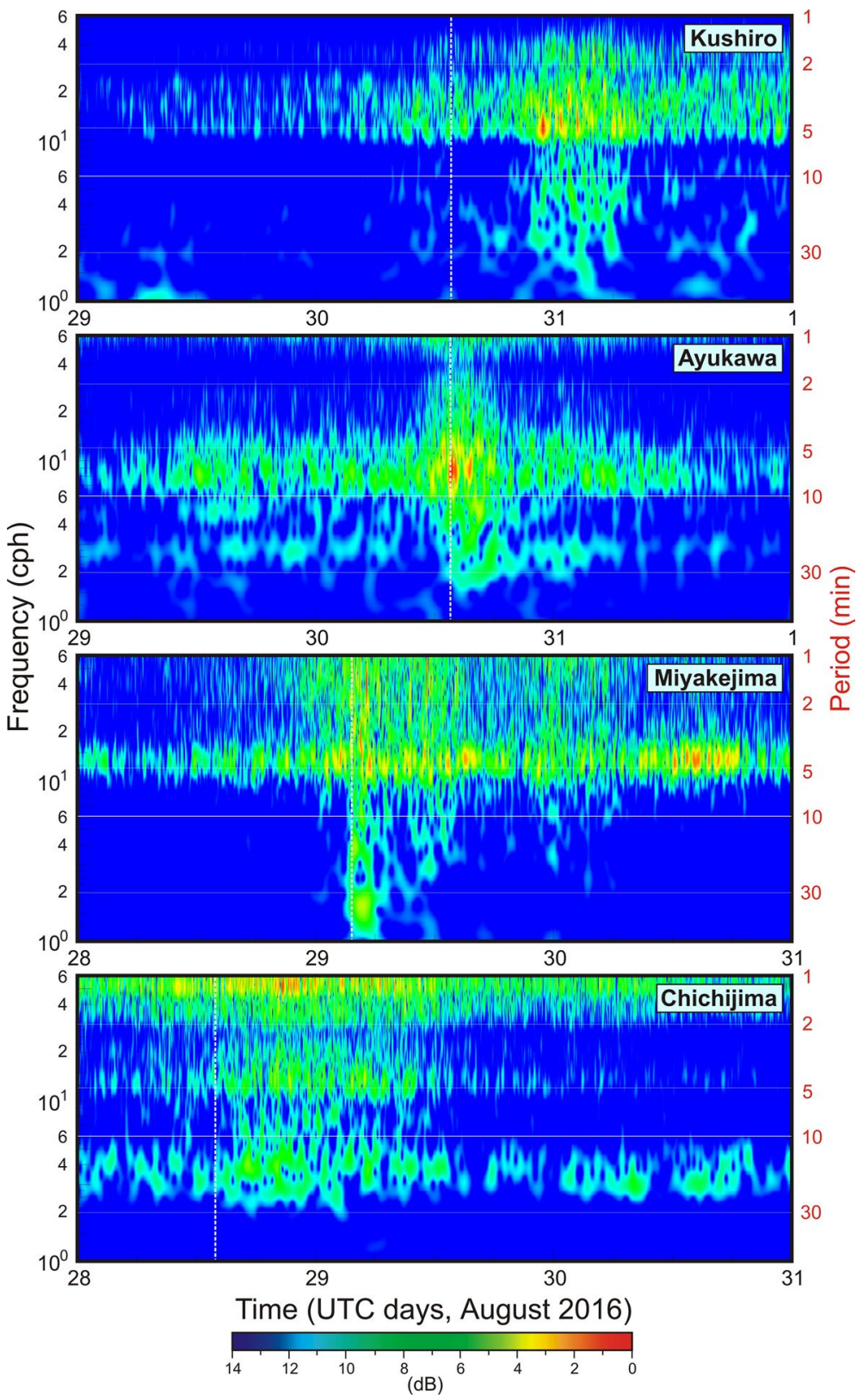

Fig. 7 Frequency-time plots ( $f-t$ diagrams) for the sea level records at four stations on the east coast of Japan during the 2016 typhoon Lionrock. The dashed vertical white line indicates the time of the typhoon core arrival (or the minimum AP time for stations not located along the typhoon's track)

the narrow-band resonant oscillations kept ringing. In general, the $f-t$ analysis demonstrates evident sea level response to the propagating typhoon and the high importance of the local resonant properties of individual harbours in the formation of hazardous floods. 
Storm-related infragravity (IG) waves with periods $<5$ min are another important factor amplifying high-frequency seiches at specific sites (for example, at Chichijima).

\section{The September 2018 Typhoon Jebi}

Typhoon Jebi was the most powerful typhoon to strike Japan in 25 years. It was formed as a tropical depression on 26 August 2018 and then rapidly intensified into a typhoon. This typhoon destructively affected the Northern Mariana Islands and then on 2 September caused huge waves and five fatalities on the coast of Taiwan. Propagating north-westward and then northward on 4 September, Jebi reached the south-eastern coast of Japan producing severe damage and intensive floods along the entire coasts of Shikoku Island and the Kansai region of Honshu Island. The typhoon existed for 15 days and ended on 9 September 2018 .

\subsection{Description of the event on the south-east coast of Japan}

Typhoon Jebi, one of the largest typhoons to ever affect Japan, left 13 dead and hundreds injured (Le et al. 2019; Mori et al. 2019). Jebi, which made landfall in west Japan (Fig. 1), caused serious disruption and damage in areas around Osaka, which is the second economic centre in Japan after Tokyo. As a result of Jebi, the normal activities at the Kansai international airport were halted for a few days (FDMA 2018) resulting in serious economic loss. The total economic losses in Japan, associated with Jebi, were estimated to be US 12.6 billion dollars, making Jebi the third costliest typhoon in the Japanese history.

With a one-minute maximum sustained wind speed of $79 \mathrm{~m} / \mathrm{s}$ (154 knots), Jebi was classified as a Category-5 hurricane in the SSHWS system. The minimum central pressure reached by Jebi was $915 \mathrm{hPa}$ on 27 August 2016 (Takabatake et al. 2018). However, Jebi then weakened to a Category-3 hurricane during landfall in east Japan (Takabatake et al. 2018). Figure 8a presents sea level pressure (SLP) time series at Kobe and Osaka (Kansai region) indicating minimum SLPs of 959 and $962 \mathrm{hPa}$, respectively. In comparison with the Lionrock AP records (Fig. 3a), the records of Jebi are sharper and deeper (Fig. 8a). A satellite image of Jebi approaching Japan is shown in Fig. 8b; the size of the typhoon system at that time (3 September 2018) was approximately $450 \mathrm{~km}$.

Significant damage on the east coast of Japan caused by Jebi was strongly associated with coastal floods. A detailed field survey description of the damage was given by Takabatake et al. (2018), Mori et al. (2019) and Le et al. (2019). Some examples of hazardous consequences of the typhoon are shown in Fig. 9: damaged road guardrails Nadakuroiwa (Fig. 9a), sea wall railings broken on the south coast of Hyogo Prefecture (Fig. 9b). Disrupted riprap revetment and wave-driven debris at the coast are presented in Figs. 9c and $9 \mathrm{~d}$, respectively.

\subsection{Observed sea level oscillations}

For analysis of sea level oscillations on the coast of Japan caused by the 2018 typhoon Jebi, we used eight stations, five on the south-eastern coast of Honshu Island (Kansai region)-Tannowa, Kumano, Sumoto, Kushimoto and Gobo-and three on the coast of Shikoku Island-Komatsujima, Murotomisaki and Tosashimizu (Fig. 1). The data with 15 -s sampling were provided by the JMA. The entire procedure for data preparation and 

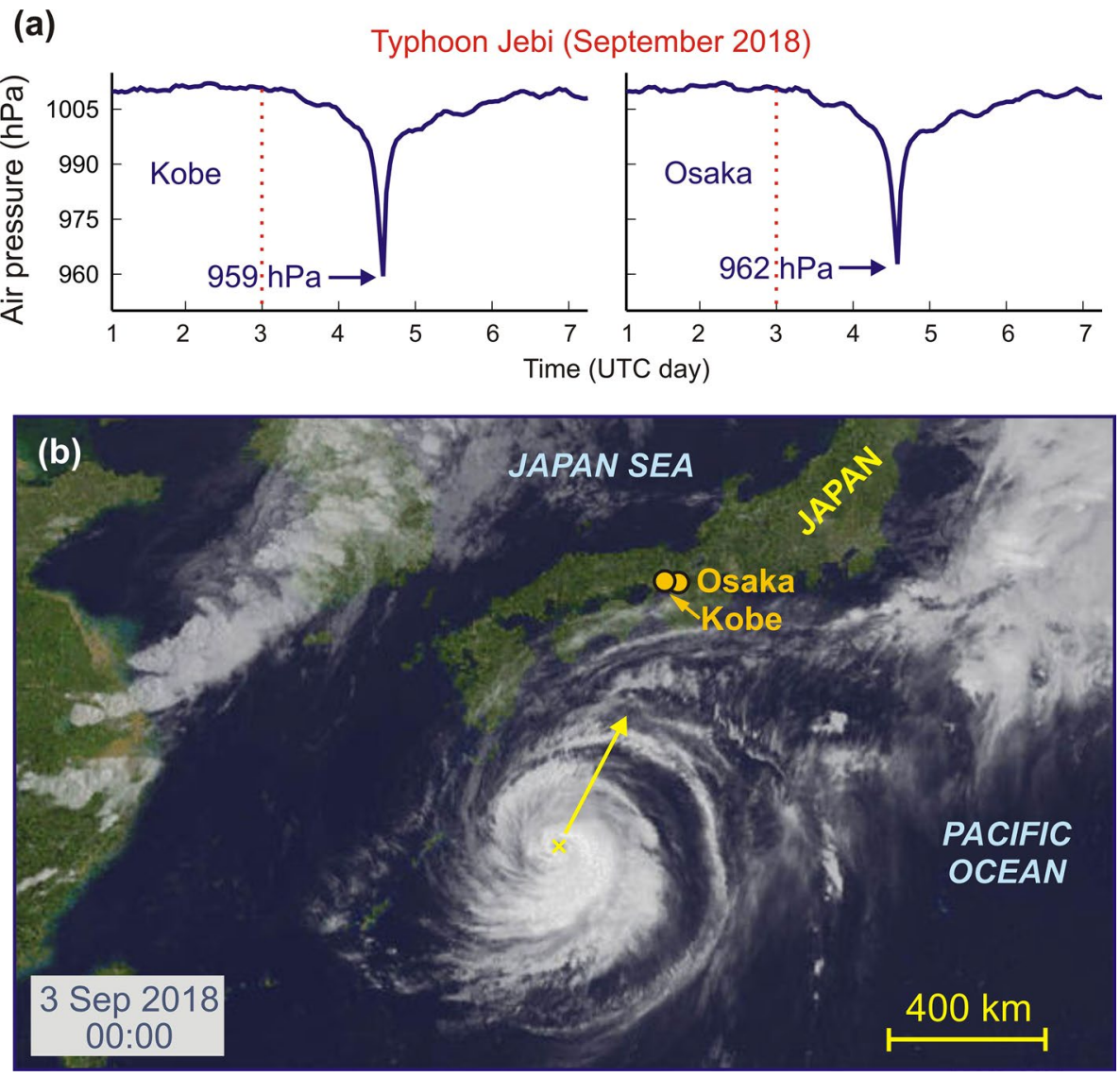

Fig. 8 a Pressure recordings at two locations along the coast of Japan during the 2018 typhoon Jebi; the dashed vertical lines indicate the time of the satellite image. b A satellite image of Typhoon Jebi on 3 September 2018. The satellite image is from https://www.hurricanezone.net/

examination was the same as for the Lionrock data (Sect. 2.2). We de-tided the original series and used a 3-h Kaiser-Bessel window (cf. Thomson and Emery 2014) to separate the storm surge from high-frequency storm seiches (meteotsunamis). The results of analyses are shown in Figs. 10 and 11, and the estimated parameters are presented in Table 2.

In general, sea level oscillations produced by typhoon Jebi were much stronger than those generated by typhoon Lionrock: the total observed sea levels were 99-288 cm (mean $151 \mathrm{~cm}$ ), in comparison with 33-120 cm (mean $66 \mathrm{~cm}$ ) for Lionrock; the Jebi surge heights were 46-173 cm (mean $102 \mathrm{~cm}$ ), while for Lionrock they were only 12-35 cm (mean $25 \mathrm{~cm}$ ). Both the maximum total height of $288 \mathrm{~cm}$ and the maximum surge height of $173 \mathrm{~cm}$ were recorded at Gobo, a small city located in the Wakayama Prefecture. This station is located exactly along the track of typhoon Jebi (Fig. 1). Substantial surges of more than $1 \mathrm{~m}$ also occurred at four other stations (Table 2).

The 2018 typhoon induced intense seiches with maximum amplitudes of $38-131 \mathrm{~cm}$ (mean $66 \mathrm{~cm}$ ) and maximum wave heights of 69-257 cm (mean $122 \mathrm{~cm}$ ). However, in contrast to the 2016 event, at most stations (at six of the eight) the surge heights were larger 


\section{Damage made by 2018 Typhoon Jebi in Japan}
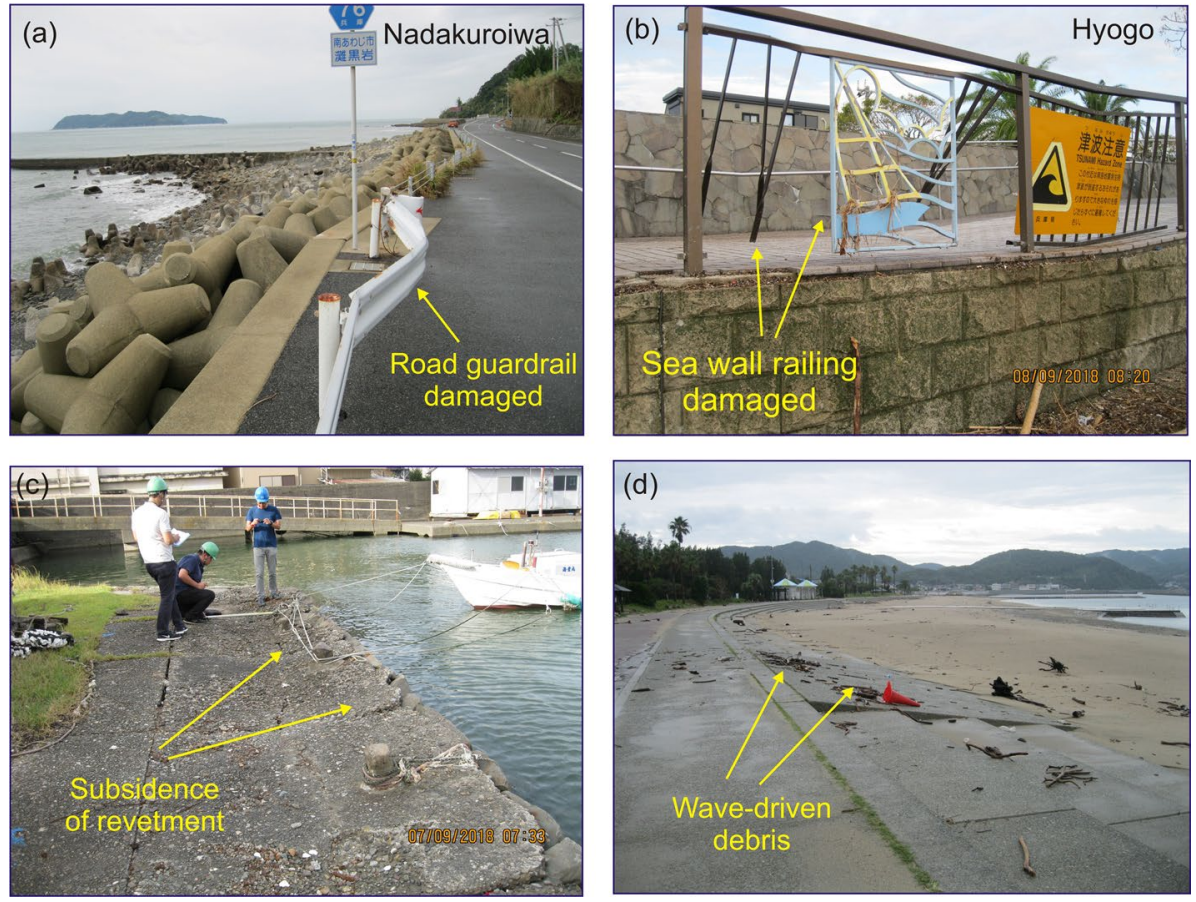

Fig. 9 Damage caused by typhoon Jebi along the south-east coast of Japan in September 2018; the photographs were made at sites located along the track of the typhoon, close to locations of stations Gobo and Tannowa (see Fig. 1 for station locations). The locations of the damage photographs are: $134.838^{\circ} \mathrm{E}$ and $34.227^{\circ} \mathrm{N}$ for $\mathbf{a} ; 135.3535^{\circ} \mathrm{E}$ and $34.713^{\circ} \mathrm{N}$ for $\mathbf{b} ; 134.700^{\circ} \mathrm{E}$ and $33.915^{\circ} \mathrm{N}$ for $\mathbf{c} ; 134.728^{\circ} \mathrm{E}$ and $34.2019^{\circ} \mathrm{N}$ for $\mathbf{d}$. Photographs belong to Mohammad Heidarzadeh

than the seiche amplitudes. The only exceptions were Kumano (46 vs $74 \mathrm{~cm}$ ) and Kushimoto (71 vs $74 \mathrm{~cm}$ ). In general, if for the 2016 Lionrock event storm surges were responsible for approximately $38 \%$ of the total height and seiches for $62 \%$, then for the $2016 \mathrm{Jebi}$ event these values were $67 \%$ and $33 \%$, respectively. This indicates that seiching was the main reason for the Lionrock floods and the storm surge for the Jebi induced floods.

Nevertheless, the seiche activity on the coasts of the Kansai region (Honshu) and Shikoku Island during the 2018 typhoon Jebi passage was quite high; seiche amplitudes varied from 38 to $131 \mathrm{~cm}$ (mean $66 \mathrm{~cm}$ ), the maximum trough-to-crest seiche heights were from 69 to $257 \mathrm{~cm}$ (mean $122 \mathrm{~cm}$ ). The latter value-a mean seiche height for eight stations of $122 \mathrm{~cm}$-makes this event extraordinary. The maximum seiche height of $257 \mathrm{~cm}$ was observed at Gobo, i.e. at the same station where the maximum surge was recorded. This height of $257 \mathrm{~cm}$ is one of the largest meteotsunami heights ever instrumentally measured anywhere in the world (cf. Rabinovich 2020; Gusiakov 2020). The total height above MSL at this station was $288 \mathrm{~cm}$; this means that to the maximum surge height of $173 \mathrm{~cm}$, seiches added $115 \mathrm{~cm}$ more, which is an enormous contribution! Similarly to what was observed for the Lionrock event, the total observed height was approximately $11 \%$ smaller than the sum of the maximum surge height and the maximum seiche amplitude. The largest 
Jebi typhoon of September 2018

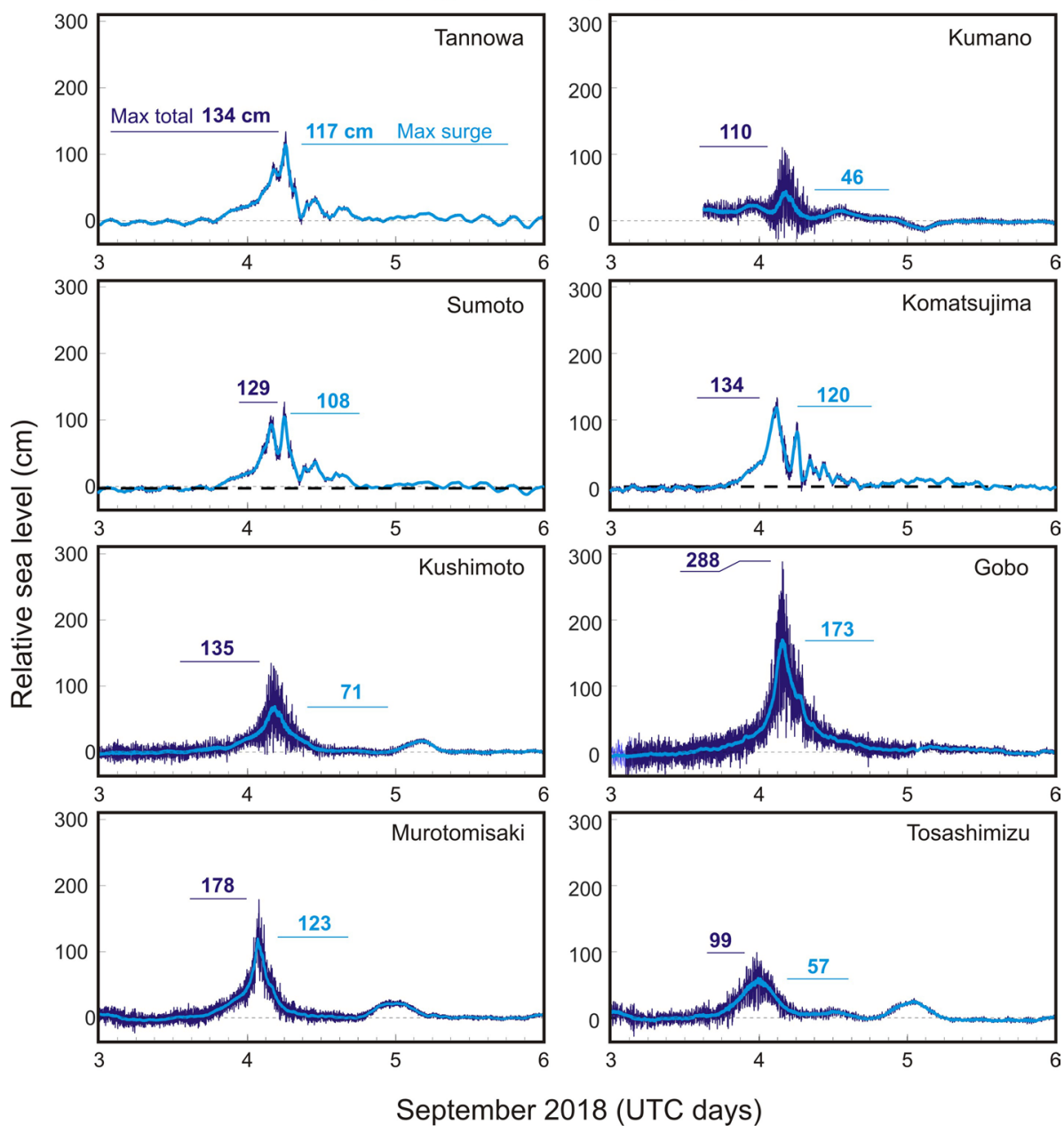

Fig. 10 Residual (de-tided) sea level records at eight stations on the coast of Japan during the 2018 typhoon Jebi passage. The thick solid black curves show the low-frequency component of the records after low-pass filtering with a 3-h Kaiser-Bessel window. The blue and purple numbers are the maximum observed (total) amplitude and the surge height, respectively

difference of $27 \mathrm{~cm}$ occurred at Sumoto (156 and $129 \mathrm{~cm}$, respectively). The main reason for this is the time lag between these two maxima.

The dominant periods of the observed seiches for the 2018 event, based on inspection of the records and $f$ - $t$ diagrams (Sect. 3.3), were from 1 to 60 min (Table 2). In comparison with those observed in 2016 (Table 1), they were more polychromatic: oscillations with 2-3 periods were observed at each station. The exact periods of the recorded oscillations vary from one site to another, but in general periods of 3-15 min prevail. 
Jebi typhoon of September 2018
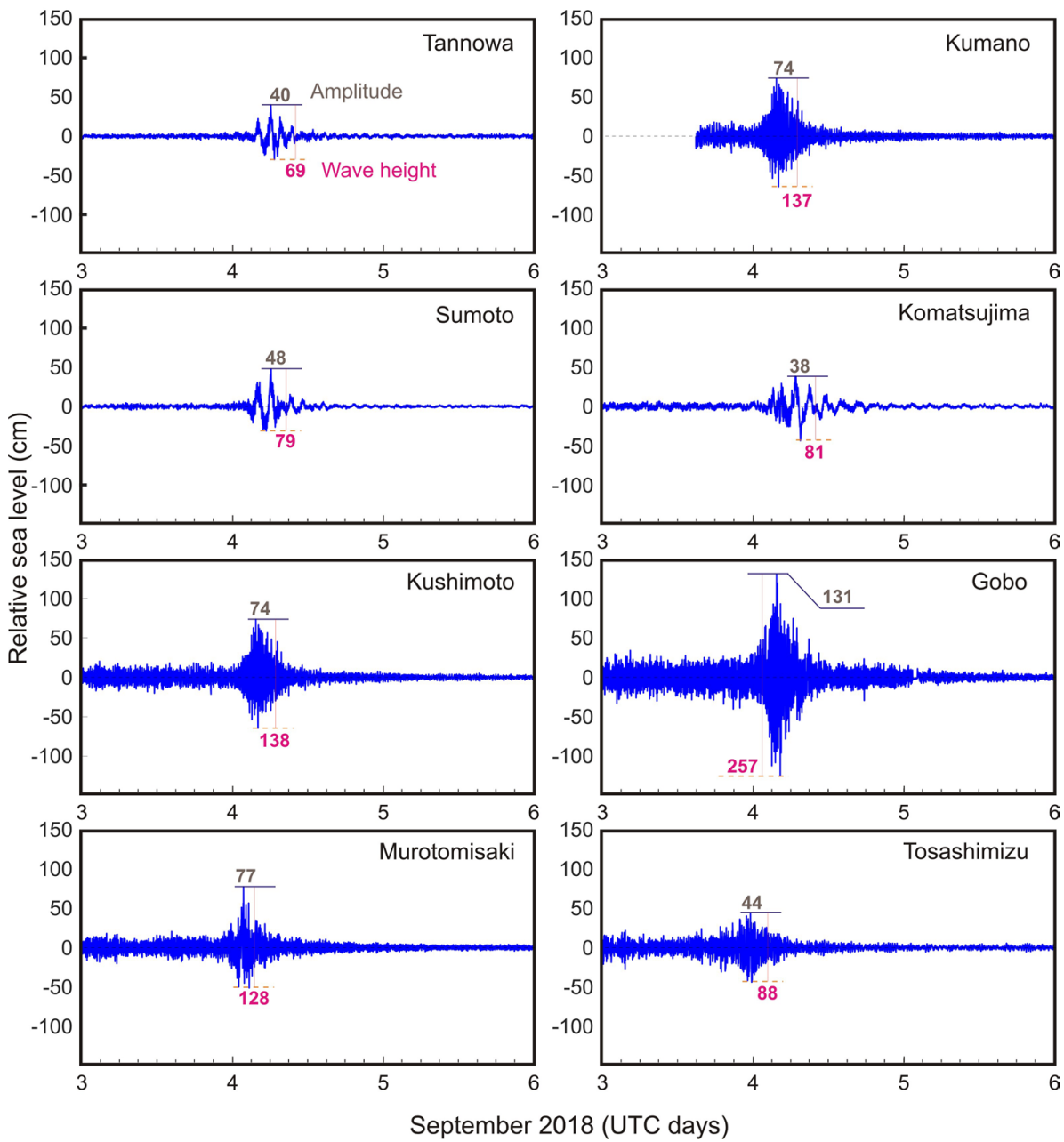

Fig. 11 The high-pass filtered (with a 3-h Kaiser-Bessel window) records of sea level oscillations at eight stations on the coast of Japan showing storm seiches (meteotsunamis) caused by the 2018 typhoon Jebi. The purple and red numbers denote the maximum amplitudes and trough-to-crest wave heights, respectively

\subsection{Time-frequency analysis}

The frequency properties/exact periods of the recorded 2018 seiche oscillations and their evolution during the typhoon's passage can be effectively examined based on the corresponding $f--t$ diagrams. The entire procedure is the same as for the 2016 oscillations (Sect. 2-4). The quality of the 2018 data was significantly higher than of the 2016 data, and this enabled us to construct respective diagrams for all examined records (Fig. 12a, b). For seven records, we used the same 3-day time segments: 3-6 September 2018. The exception was Kumano: the available original record at this station started on 4 September 
Table 2 Locations of tide gauge stations and observed surge/seiche parameters of the corresponding records during the 2018 Typhoon Jebi (Japan)

\begin{tabular}{|c|c|c|c|c|c|c|c|}
\hline \multirow[t]{2}{*}{ Station } & \multicolumn{2}{|l|}{ Coordinates } & \multirow{2}{*}{$\begin{array}{l}\text { Observed } \\
\text { (total) } \\
\text { height }(\mathrm{cm})\end{array}$} & \multirow{2}{*}{$\begin{array}{l}\text { Surge } \\
\text { height } \\
(\mathrm{cm})\end{array}$} & \multicolumn{3}{|c|}{ Seiches (meteotsunami) } \\
\hline & $\begin{array}{l}\text { Longitude } \\
\left({ }^{\circ} \mathrm{E}\right)\end{array}$ & $\begin{array}{l}\text { Latitude } \\
\left({ }^{\circ} \mathrm{N}\right)\end{array}$ & & & $\begin{array}{l}\text { Max } \\
\text { amplitude } \\
(\mathrm{cm})\end{array}$ & $\begin{array}{l}\text { Max height } \\
(\mathrm{cm})\end{array}$ & Period $(\min )$ \\
\hline Tannowa & 135.183 & 34.333 & 134 & 117 & 40 & 69 & 13,50 \\
\hline Kumano & 136.167 & 33.933 & 110 & 46 & 74 & 137 & $1,3,10$ \\
\hline Sumoto & 134.900 & 34.250 & 129 & 108 & 48 & 79 & 5,60 \\
\hline Komatsujima & 134.583 & 34.017 & 134 & 120 & 38 & 81 & $3,7,30$ \\
\hline Kushimoto & 135.767 & 33.483 & 135 & 71 & 74 & 138 & 3,9 \\
\hline Gobo & 135.167 & 33.850 & 288 & 173 & 131 & 257 & 5,10 \\
\hline $\begin{array}{l}\text { Murotomi- } \\
\text { saki }\end{array}$ & 134.167 & 33.267 & 178 & 123 & 77 & 128 & $2.5,8$ \\
\hline Tosashimizu & 132.967 & 32.783 & 99 & 57 & 44 & 88 & 4,25 \\
\hline
\end{tabular}

(see Figs. 10 and 11); therefore, the respective $f-t$ diagram started $25.5 \mathrm{~h}$ later than for the other stations (Fig. 12b).

Despite the evident differences between oscillations (in particular, in wave heights and periods) observed at each site, there was a remarkable common feature: the strong broadband amplification of these oscillations during the typhoon's passage. A 7-h band of highly energetic oscillations in the $f-t$ diagrams of all stations corresponds roughly to the mid day of 4 September 2018 and includes the entire frequency band of 1-60 cph (periods of 60 to $1 \mathrm{~min}$ ). This evidence of a broad-band external (atmospheric) forcing, producing a broadband sea level response. At the same time, there are specific frequencies with pronounced energy peaks: $12 \mathrm{cph}(5 \mathrm{~min})$ at Gobo, 20 and $7 \mathrm{cph}(3$ and $9 \mathrm{~min})$ at Kushimoto, 24 and $7.5 \mathrm{cph}$ (2.5 and $8 \mathrm{~min})$ at Murotomisaki, 15 and $2.4 \mathrm{cph}(4$ and $25 \mathrm{~min})$ at Tosashimizu (Fig. 12a), $2 \mathrm{cph}$ (30 min) at Komatsujima, 4.5 and $1.2 \mathrm{cph}$ (13 and $50 \mathrm{~min}$ ) at Tannowa, $12 \mathrm{cph}(5 \mathrm{~min})$ at Sumoto and 20 and $6 \mathrm{cph}$ (3 and $10 \mathrm{~min})$ at Kumano. As can be seen, almost all these peaks correspond to the definite frequency bands of increased energy that appear to be associated with the resonant (eigen) frequencies of the respective sites (they are evident in both background and event segments of the $f$-t diagrams). This means that the typhoon had generated sea level oscillations in a wide range of frequencies, but the strongest response occurs at the resonant frequencies. The entire character of seiche generation by the propagating 2018 typhoon was comparable to that for the 2016 typhoon Lionrock (Fig. 7). Similar to the 2016 event, the broad-band oscillations decay quickly after the 2018 typhoon's passage, while narrow-band oscillations at resonant frequencies keep reverberating. In general, we may conclude that local topography (eigen properties of specific harbours and bays) plays a critical role in the generation of the extreme seiches, which can be considered as meteotsunamis. In this regard, these conclusions are in good agreement with those by Honda et al. (1908) and Nomitsu (1935), who were the first to show that the resonant properties of specific sites are central to the formation of tsunamis and tsunami-like waves on the coast of Japan. 

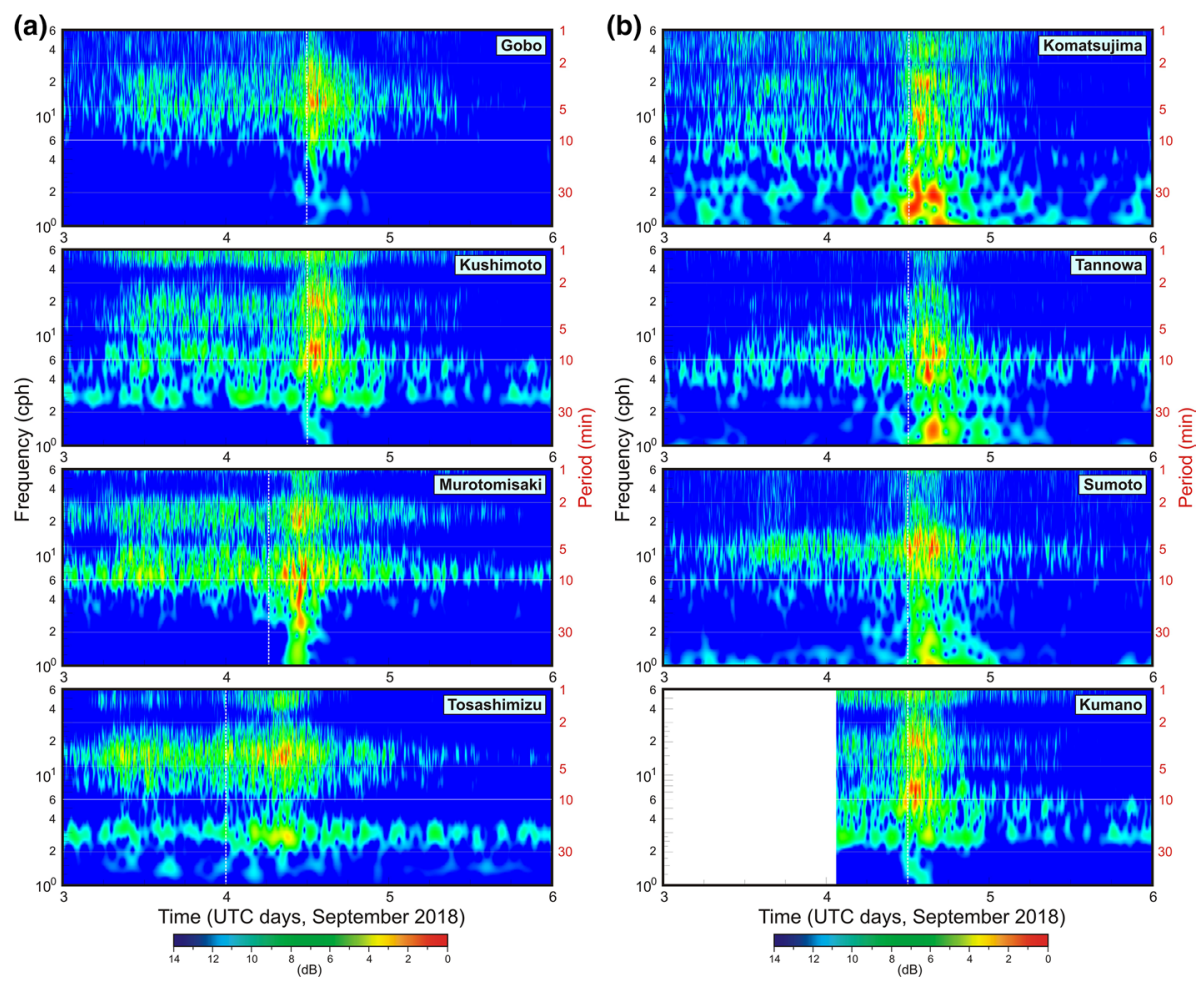

Fig. 12 a. Frequency-time plots ( $f$ - $t$ diagrams) for the sea level records at stations Gobo, Kushimoto, Murotomisaki and Tosashimizu (south-eastern Japan) during the 2018 typhoon Jebi. The dashed vertical white line indicates the time of the typhoon core arrival (or the minimum AP time for stations not located along the typhoon's track). b Same as in a for stations Komatsujima, Tannowa, Sumoto and Kumano

\section{Combined effect of surges and seiches and associated currents}

Both storm surges and meteotsunamis are damaging natural hazards, but combined together they are becoming much more destructive. This is a typical situation for typhoons and hurricanes impacting the coastal zones of Japan, USA, Mexico, Caribbean countries, India and some other regions. However, there are very few studies trying to examine the contribution of this cumulative effect (cf. Roeber and Bricker 2015; Bajo et al. 2019). In the present study, we used the sea level data from two intense typhoons, Lionrock and Jebi, that struck Japan in August 2016 and September 2018, respectively. These typhoons induced both storm surges and intense seiches; the two types of sea level oscillations merged together, roughly doubled the hazardous effect, and produced devastating floods along the east coast of Japan.

Figure 13 illustrates the relative contribution of storm surges and seiches (meteotsunamis) into the absolute sea level heights during the 2016 and 2018 events. The area of inner (magenta) circles is proportional to the storm surge heights, the blue rings indicate the seiche supplement, and the areas of the entire circles are proportional to the total observed heights shown in Figs. 5 and 10 and indicated in Tables 1 and 2. The relative impact of surges and seiches is different for the two events; in particular, it is seen that for the 2016 


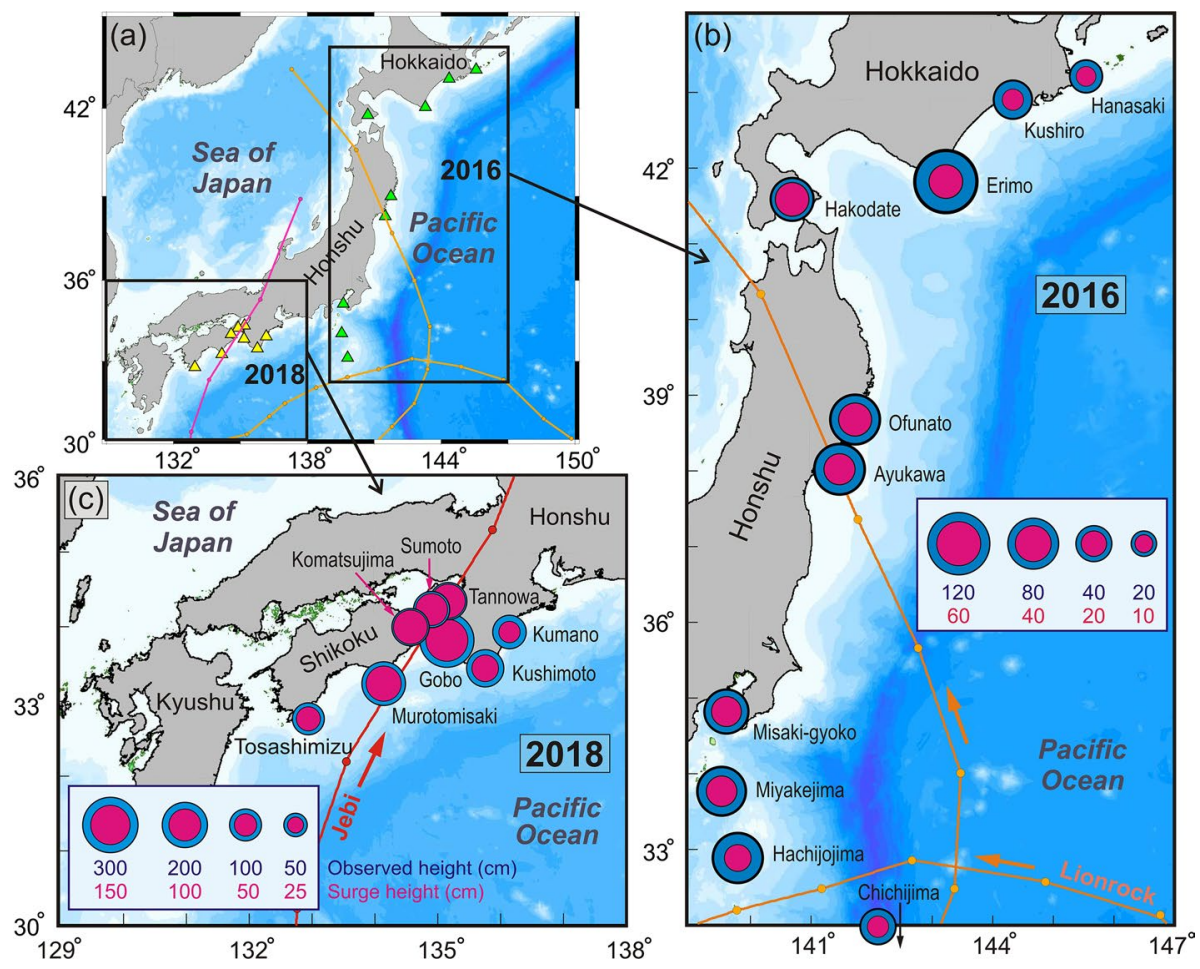

Fig. 13 Contribution of storm surges (magenta circles) and seiches (blue rings) into destructive sea level variations and associated floods caused by b the August 2016 typhoon Lionrock and $\mathbf{c}$ the September 2018 typhoon Jebi. The area of the inner (magenta) circles is proportional to the surge height, while the total area of the circle (including blue rings) is proportional to the total observed height. The location of Chichijima is displaced in panel "b"

event the seiches prevailed, while for the 2018 event the surge contribution was larger. But in general, both components were important, strongly amplifying the resulting flood. It can be seen that for Lionrock the surge heights remain approximately the same for all stations along the track of the typhoon (e.g. Ayukawa and Ofunato), as well as for stations far from the track (e.g. Erimo and Misaki-gyoko). However, for typhoon Jebi, the stations located directly along the track (e.g. Gobo and Murotomisaki) had much higher surges than those located off the track (e.g. Kumano). This could be attributed to the spans of the corresponding typhoons and associated distributions of atmospheric pressure: the respective cloud systems indicate that Lionrock was approximately $900 \mathrm{~km}$ in diameter (Fig. 3b), whereas Jebi's diameter was around $450 \mathrm{~km}$ (Fig. 8b). Therefore, Lionrock affected a much wider region in comparison to Jebi. However, Jebi had lower air pressures (compare Figs. 3a and 8a) and, consequently, created a substantially stronger surge.

Storm-generated seiches/meteotsunamis, however, are perilous not only because they supplement significant additional height to storm surges and enlarge the flood. What is even more important are the extreme currents that accompany seiche oscillations. Current speeds arising from wave-like motions entering into a bay or harbour are directly proportional to the wave height and inversely proportional to the wave period. The typical meteotsunami period of $\sim 15 \mathrm{~min}$ for the fundamental (Helmholtz) eigen-mode is approximately 
50 times smaller than the predominant 12.5 -h semidiurnal (SD) tidal period. This means that seiche/meteotsunami currents will be fifty times stronger than tidal currents caused by a tide of the same height. For example, if tidal currents on the shelf or in narrows are $10-15 \mathrm{~cm} / \mathrm{s}$, then the meteotsunami currents can be $\sim-7.5 \mathrm{~m} / \mathrm{s}(10-15 \mathrm{knots})$. Typical durations of storm surges are even longer than tidal periods; therefore, storm generated seiche currents are approximately two orders faster than those associated with the respective storm surge.

Recently, tsunami generated currents began to attract much attention. Dengler et al. (2008), Borrero et al. (2015), Wilson et al. (2013), and Admire et al. (2014) reported significant damage at maritime facilities and harbour infrastructure produced by tsunami currents in ports of California and New Zealand caused by the 2006 Kuril, 2010 Chile and 2011 Tohoku trans-oceanic tsunamis. In particular, in November 2006, the harbour at Crescent City (California) was strongly affected by tsunami currents resulting from the $M_{\mathrm{w}} 8.3$ earthquake in the Kuril Islands; the total damage was almost $\$ 20$ million (Dengler et al. 2008; Wilson et al. 2013). After the 2010 Chile earthquake tsunami currents of up to 16 knots $(8 \mathrm{~m} / \mathrm{s})$ caused severe damage to docks in San Diego, Catalina Island, Ventura, and Santa Cruz (California) (Wilson et al. 2013). Lynett et al. (2014) and Borrero et al. (2015) presented many other historical examples of destructive tsunami currents in various regions of the world oceans. Quite often intense tsunami currents are observed in far-field ports, where no flood inducing water levels was recorded; these currents can appear many hours after the initial tsunami arrival and last for two-three days.

Strong tsunami-induced currents and associated eddies and swirls repeatedly occur along the coast of Japan. Thus, Horikawa (1961), following the 1960 Chilean tsunami, reported such currents in Susaki Port on Shikoku Island and at some other sites in Japan. At Hachinohe (the north-eastern coast of Hokkaido Island) 10-knot currents broke moorings, while at Miyako, located on the same coast (Fig. 1), currents of 5-8 knots impeded vessel traffic. The 2011 Tohoku tsunami provided a large set of observational and instrumental data, including the most vivid example of rotational (eddy) currents in the Port of Oarai, located on the east coast of Honshu about $100 \mathrm{~km}$ north from Tokyo (Lynett et al. 2012) Inazu et al. (2018). presented a wide collection of ship navigation records indicating that tsunami currents during the 2011 tsunami were observed in numerous bays and harbours along the Pacific coast of Japan. Hence, highly intense currents are a common feature of tsunami events in Japan, and we may assume the same situation for meteotsunami currents.

There are several known events when relatively small-height meteotsunamis were accompanied by hazardous currents. In particular, on 27 June 2003 a meteotsunami on the west coast of Croatia affected Stari Grad Bay (Hvar Island) and Mali Ston Bay (near the isthmus of the Pelješac Peninsula). The meteotsunami, which are known locally as "šćiga", caused flooding in the seafront of Stari Grad and swift currents at Mali Ston, resulting in strong damage to shellfish farms in the corresponding bay, despite the fact that that the sea level oscillations at this site were only $40 \mathrm{~cm}$ (Vilibic et al. 2004). According to Pattiaratchi and Wijeratne (2015), the meteotsunami of 17 August 2014 in Perth, Australia, produced strong currents of $>1 \mathrm{~m} / \mathrm{s}$ ( 2 knots), which resulted in the breakage of moorings and damage to ships inside the Fremantle Port. A tragic event occurred on the Warren Dunes State Park beach (Lake Michigan) on 4 July 2003: a moderate-height $(\sim 0.3 \mathrm{~m})$ meteotsunami generated strong offshore currents that drowned seven people (Linares et al. 2019). Similar disastrous accidents were reported in this region in the past (Great Lakes Current Incident Database; http://www. miseagrant.umich.edu/dcd/dcdsearch.php). Several meteotsunami events in British 
Columbia (Canada) have been identified not because of significant sea level oscillations, but because of anomalous extreme flows in coastal zones reported by eyewitnesses; such currents can cause damage to yachts, boats and port infrastructure (Thomson et al. 2009; Rabinovich et al. 2020).

Thus, storm seiches superimposed on storm surges not only increase the flooding effect, but can also produce extreme currents and major associated damage. Lynett et al. (2014) provided a special study to correlate tsunami current speed to the damage introduced:

(i) : Current speed $<3$ knots $(<1.5 \mathrm{~m} / \mathrm{s})$ No damage;

(ii) : Current speed $=3-6$ knots $(1.5-3 \mathrm{~m} / \mathrm{s})$ Minor/moderate damage possible;

(iii) : Current speed $=6-9$ knots $(3-4.5 \mathrm{~m} / \mathrm{s})$ Major damage possible;

(iv) : Current speed $>9$ knots $(>4.5 \mathrm{~m} / \mathrm{s})$ Extreme damage possible.

There were no current measurements at the examined sites during the 2016 and 2018 events or, at least, they are unknown to the authors of the present study. However, the corresponding speeds may be roughly estimated based on seiche amplitudes and water depths within the harbours. According to Sorensen (2010), the maximum current speed, $V_{\max }$, can be evaluated as:

$$
V_{\max }=A \sqrt{g / H}
$$

where $g$ is the gravity acceleration, $H$ is the water depth, and $A$ is the zero-to-crest maximum amplitude of the seiche. The values of $A$ were taken from Tables 1 and 2, while the water depth $(H)$ at the respective harbours was taken from the following website: https:// webapp.navionics.com. The estimated current speeds for the corresponding sites are presented in Table 3 and shown in Fig. 14. The 2018 seiche amplitudes $(A)$ were higher than those in 2016; consequently, the estimated "Jebi currents" were stronger than the "Lionrock currents". We note that Eq. (1) implies that the current speed is directly correlated with the seiche amplitude and is inversely related to the water depth in the harbour.

The speed values in Table 3 should be considered as very approximate: in certain port/ harbour narrows the currents can be even faster. Also, as indicated by Borrero et al. (2015), large eddies and whirlpools are often generated in ports and harbours during tsunamis and these features lead to intense, dynamic and persistent currents, which can be much stronger than estimated by Eq. (1). However, even these preliminary estimates demonstrate that during the 2016 event currents at Erimo, Hachijojima and probably Miyakejima, were strong enough to create damage to anchored boats and cargo vessels and to substantially affect port facilities. The meteotsunami currents caused by typhoon Jebi were substantially stronger; it appears that at Gobo, Kushimoto and Murotomisaki they were of 4-6 knots, while at other examined sites they were $2-3$ knots. The reported destruction of port facilities and boats during the 2018 event was probably produced by these currents.

\section{Discussion and perspectives}

The seiche oscillations and associated currents generated by 2018 typhoon Jebi were much more intense than those generated by 2016 typhoon Lionrock. Three factors could potentially be the reason for this difference: (a) the stronger forcing of the 2018 event; (b) the more effective parameters of the 2018 typhoon for seiche (meteotsunami) generation; (c) 
Table 3 Estimation of the storm current speed at tide gauge locations along the coast of Japan during the 2016 typhoon Lionrock and 2018 typhoon Jebi

\begin{tabular}{|c|c|c|c|c|}
\hline Event & Station & Water depth* $(\mathrm{m})$ & $\begin{array}{l}\text { Max seiche } \\
\text { amplitude }(\mathrm{cm})\end{array}$ & Current speed $(\mathrm{m} / \mathrm{s})$ \\
\hline \multirow[t]{11}{*}{2016 Typhoon Lionrock } & Hanasaki & $2.0-5.0$ & 22 & $0.3-0.4$ \\
\hline & Kushiro & $5.0-10.0$ & 34 & $0.4-0.6$ \\
\hline & Erimo & $2.0-5.0$ & 92 & $1.2-1.9$ \\
\hline & Hakodate & $5.0-10.0$ & 26 & $0.2-0.3$ \\
\hline & Ofunato & $5.0-10.0$ & 45 & $0.4-0.6$ \\
\hline & Ayukawa & $5.0-10.0$ & 52 & $0.5-0.7$ \\
\hline & Misaki-gyoko & $2.0-5.0$ & 35 & $0.5-0.8$ \\
\hline & Miyakejima & $1.0-2.0$ & 51 & $1.0-1.4$ \\
\hline & Hachijojima & $1.0-2.0$ & 56 & $1.2-1.7$ \\
\hline & Chichijima & $1.0-2.0$ & 30 & $0.6-0.9$ \\
\hline & Mean speed & & & $0.6-0.9$ \\
\hline \multirow[t]{9}{*}{2018 Typhoon Jebi } & Tannowa & $1.0-2.0$ & 40 & $0.8-1.1$ \\
\hline & Kumano & $2.0-5.0$ & 74 & $1.0-1.5$ \\
\hline & Sumoto & $1.0-2.0$ & 48 & $0.9-1.2$ \\
\hline & Komatsujima & $2.0-5.0$ & 38 & $0.6-0.9$ \\
\hline & Kushimoto & $1.0-2.0$ & 74 & $1.5-2.2$ \\
\hline & Gobo & $2.0-5.0$ & 131 & $1.8-2.9$ \\
\hline & Murotomisaki & $1.0-2.0$ & 77 & $1.4-2.0$ \\
\hline & Tosashimizu & $1.0-2.0$ & 44 & $1.0-1.4$ \\
\hline & Mean speed & & & $1.1-1.7$ \\
\hline
\end{tabular}

*Variations of water depth at the location of each tide gauge according to the information from https:// webapp.navionics.com

specific resonant properties of the sites affected by the 2018 typhoon. In the following text, these factors are discussed one by one:

(a) As evident in a comparison of Figs. 8a and 3a, typhoon Jebi was stronger and deeper than typhoon Lionrock; the minimum air pressure at the east coast of Japan was $<959 \mathrm{hPa}$ for Jebi and $\sim 970 \mathrm{hPa}$ for Lionrock. What is especially important: Jebi was more compact and "sharper" than Lionrock (Figs. 8a and 3a); this means that the spatial AP gradients for Jebi were significantly larger. Consequently, Jebi was characterized by extremely fast winds; up to $46.5 \mathrm{~m} / \mathrm{s}$ (gusts of more than $55 \mathrm{~m} / \mathrm{s}$ ) in the Kansai region, while the maximum Lionrock winds over Japan were up to $35 \mathrm{~m} / \mathrm{s}$. It is natural that a stronger atmospheric event could produce a stronger sea level response.

(b) The effectivity of meteotsunami/seiche generation strongly depends on parameters of the propagating atmospheric disturbances (Rabinovich and Monserrat 1998). The most important tsunamigenic air pressure (AP) parameters are the speed and direction of the disturbance's propagation (cf. Orlić et al. 2010; Rabinovich et al. 2020). The most effective generation occurs during the Proudman resonance (cf. Hibiya and Kajiura 1982; Monserrat et al 2006; Šepić et al 2015), when the speed of the AP disturbances, $U$, is approximately equal to the longwave speed of ocean waves, $c=\sqrt{g H}$, i.e. when $U \approx c$ and the Froude number, $F r=U / c \approx 1.0$ (Šepić et al. 2015), and the AP directed 

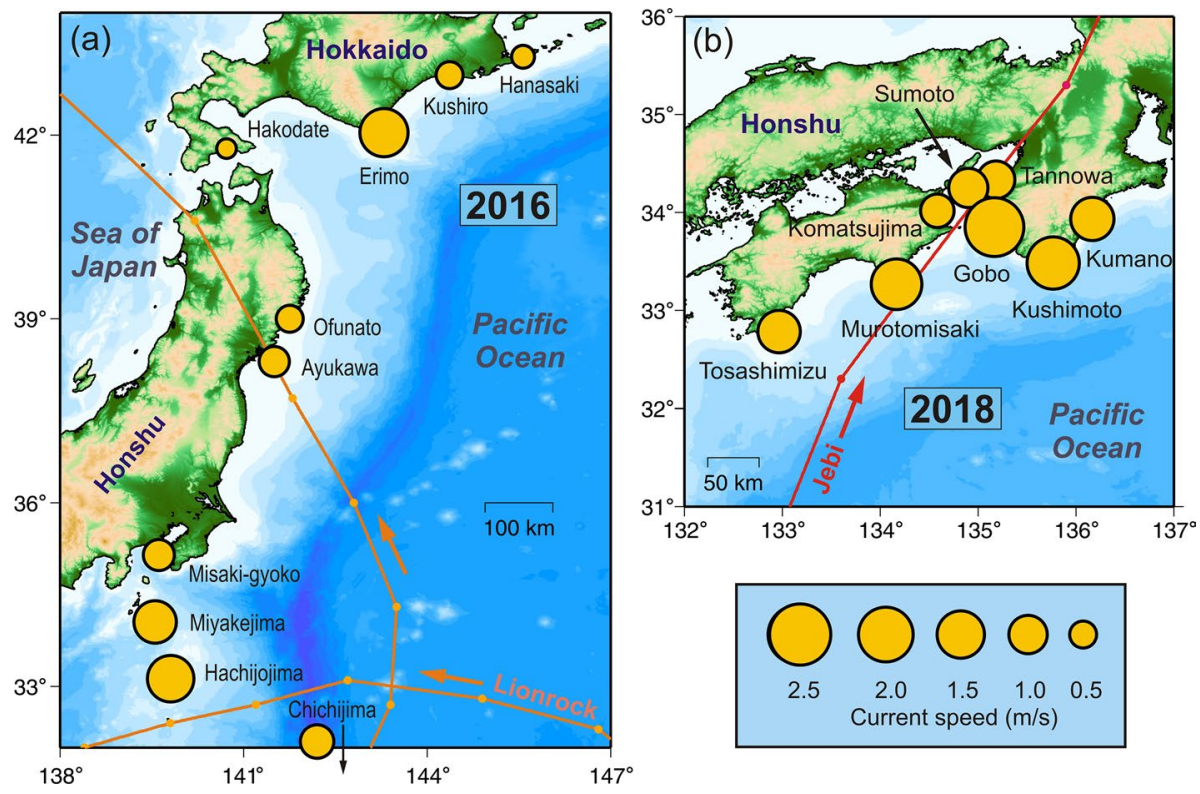

Fig. 14 Estimated current speeds (yellow circles) associated with storm seiches (meteotsunamis) caused by a August 2016 typhoon Lionrock and b September 2018 typhoon Jebi. The diameters of the circles are proportional to the current speed. The location of station Chichijima is shown in the inset in Fig. 1

towards the bay/harbour entrance (Rabinovich and Monserrat 1998). However, some other parameters are also important, in particular, the frequency composition of the corresponding disturbance relative to the eigen frequencies of the respective site (Rabinovich and Monserrat 1998).

A remarkable example of resonant generation of extreme seiches was described by Mitsuta and Yoshizumi (1968). An extraordinarily strong typhoon (No. 6618, Cora) with a minimum AP of 918 hPa propagated over Miyakojima Island (the Ryukyu Islands, Japan). An analogue barograph at the Miyakojima Weather Station recorded regular AP oscillations with a monochromatic period of $\sim 50$ min and a double amplitude of up to $15 \mathrm{hPa}$ overlapping the general $\mathrm{V}$-shaped pressure change. These oscillations induced simultaneous sea level oscillations of the same period with a maximum trough-to-crest wave height of $115 \mathrm{~cm}$, i.e. almost 8 times stronger than the AP oscillations (according to the inverse barometer response). We do not know the exact reason for anomalously strong seiche oscillations during 2018 typhoon Jebi, but we can assume that certain parameters of this typhoon, including its speed, direction and frequency content, were favourable for intense seiche generation.

(c) As was mentioned above, there are specific sites around the world where meteotsunamis/extreme seiches occur regularly and achieve large heights: Ciutadella Harbour (Menorca Island, Spain), Vela Luka (Korčula Island, Croatia), Mazara del Vallo (Sicily, Italy), Longkou Harbour (China) and Nagasaki Bay (Japan) (Rabinovich and Monserrat 1996; Monserrat et al. 2006; Rabinovich 2020). At these sites, even moderate atmospheric disturbances can produce a strong sea level response. Šepić and Rabinovich (2014) introduced the "generation coefficient" parameter to characterize the efficiency of meteotsunami generation at various sites: 


$$
R_{\max }^{j}=\left(h_{\max }^{j}\right) /\left(\Delta P_{\max }^{j}\right)
$$

where $h_{\max }^{j}$ is the maximum recorded trough-to-crest height of generated sea level oscillations at $j$ th station and $\Delta P_{\max }^{j}$ is the height of the respective air pressure disturbance. This enabled Šepić and Rabinovich (2014) to identify "hot spots" in the area of the Great Lakes and on the northeastern Atlantic coast of the USA, i.e. sites with enlarged sea level response and expected meteotsunamis: Port Calumet (Illinois); Atlantic City, Sandy Hook and Bergen Point (all in New Jersey). Similarly, Dusek et al. (2019) examined 10-20-year data series (1996-2017) from tide gauge stations along the US East Coast, Caribbean and Bermuda and found that large meteotsunamis regularly occur at a few sites: Atlantic City, Cape Hatteras, Providence, and Port Canaveral. Because of certain combinations of shelf topography and coastal geometry these sites on the Atlantic coast of the USA are hot spots.

The question is: Could the sites on the coast of Japan, where the strongest seiches were recorded during the 2016 and 2018 events, also be considered as "hot spots"? Two events are not enough to answer this question, especially taking into account that the 2016 and 2018 typhoons affected different parts of the Japanese coast and the corresponding seiche oscillations were recorded at different stations. Regrettably, we do not have high-resolution air-pressure data, similar to those used by Šepić and Rabinovich (2014) to estimate the "generation coefficient" for various sites on the East Coast of the USA. Therefore, we cannot estimate this coefficient for 18 sites examined in our paper for the 2016 and 2018 events, but we can assume that the sites with maximum recorded high-frequency oscillations (meteotsunamis) during these two events are "hot". Specific topographic features, in particular the funnelling effect of coastal topography (see Figs. 1b and 1c), can significantly amplify incoming waves. An additional important factor responsible for generation of destructive meteotsunamis is the Proudman resonance, $U \approx c$. However, both typhoons were approaching the coast of Japan with relatively slow speed, $U=15-20 \mathrm{~km} / \mathrm{h}$ (Fig. 1a), while the shelf depths in the areas of the typhoon landfalls were rather large (Figs. 1b, c); therefore, this effect could not be responsible for extreme seiches during the 2016 and 2018 events.

A natural approach would be to compare these two events with some historical events, described in the literature. Unfortunately, there are too few papers on analysis of recorded seiche heights in Japan. The most comprehensive study of this question was done by Nakano and Unoki (1962), i.e. almost 60 years ago. They examined multiyear series of seiche oscillations (known in Japan as "secondary undulations of tides") at 45 tide gauge stations located in various harbours and bays of the Japanese coast, including five stations that were examined in the present paper: Kushiro, Ayukawa and Chichijima (2016), Kushimoto and Tannowa (2018). The maximum wave heights recorded at these five stations are given in Table 4.

The data presented in Table 4 enable us to make certain conclusions:

- Stations Kushiro, Chichijima and Tannowa cannot definitely be considered as "hot spots"; maximum historical wave heights of atmospherically induced seiches at these stations were significantly smaller than those measured during the 2016 and 2018 typhoons and, in fact, less than $54 \mathrm{~cm}$.

- Stations Kushimoto and Ayukawa potentially can be considered as hot spots: seiche heights of more than $1 \mathrm{~m}$ had been recorded several times at these stations in the past and also during the 2016 or 2018 events. 
Table 4 Maximum recorded historical non-seismic trough-to-crest seiche heights at five stations examined in the present study, according to the analyses of Nakano and Unoki (1962)

\begin{tabular}{|c|c|c|c|c|c|c|}
\hline Station & $\begin{array}{l}\text { Observa- } \\
\text { tion period } \\
\text { (years) }\end{array}$ & $\begin{array}{l}\text { Date (yyyy/ } \\
\text { mm/dd) }\end{array}$ & $\begin{array}{l}\text { Seiche } \\
\text { duration } \\
\text { (hours) }\end{array}$ & Period (min) & $\begin{array}{l}\text { Wave height } \\
(\mathrm{cm})\end{array}$ & Source \\
\hline Kushiro* & 1947-1956 & - & - & - & $<54(79)$ & \\
\hline Ayukawa & 1943-1956 & $\begin{array}{l}1955 / 12 / 26 \\
1946 / 03 / 04\end{array}$ & $\begin{array}{l}16 \\
75\end{array}$ & $\begin{array}{l}8 \\
6\end{array}$ & $\begin{array}{l}117(102) \\
108\end{array}$ & $\begin{array}{l}\text { Low pressure } \\
\text { over the Sea } \\
\text { of Japan } \\
\text { Frontal line and } \\
\text { low pressure }\end{array}$ \\
\hline Chichijima & 1933-1944 & $\begin{array}{l}1943 / 02 / 06 \\
1941 / 02 / 14\end{array}$ & $\begin{array}{l}4 \\
2\end{array}$ & $\begin{array}{l}16 \\
19\end{array}$ & $\begin{array}{l}46(58) \\
30\end{array}$ & $\begin{array}{l}? \\
?\end{array}$ \\
\hline Kushimoto & 1934-1956 & $\begin{array}{l}1952 / 11 / 05 \\
1952 / 02 / 18 \\
1953 / 09 / 24\end{array}$ & $\begin{array}{l}72 \\
32 \\
39\end{array}$ & $\begin{array}{l}12 \\
20 \\
2\end{array}$ & $\begin{array}{l}143(138) \\
125 \\
122\end{array}$ & $\begin{array}{l}\text { Typhoon Agnes } \\
\text { Front } \\
\text { Typhoon Tess }\end{array}$ \\
\hline Tannowa & 1949-1956 & $\begin{array}{l}1953 / 02 / 12 \\
1953 / 07 / 05 \\
1956 / 08 / 17\end{array}$ & $\begin{array}{l}33 \\
11 \\
23\end{array}$ & $\begin{array}{l}7 \\
30 \\
9\end{array}$ & $\begin{array}{l}29(69) \\
29 \\
29\end{array}$ & $\begin{array}{l}\text { Stationary front } \\
\text { Stationary front } \\
\text { Typhoon Babs }\end{array}$ \\
\hline
\end{tabular}

The observation periods at various sites are indicated. Maximum seiche heights recorded at these stations during 2016 typhoon Lionrock or 2018 typhoon Jebi are given in brackets following the historical maximum heights in column "Wave height $(\mathrm{cm})$ "

*The only data indicated by Nakano and Unoki (1962) are for the 1952 Kamchatka earthquake $(95 \mathrm{~cm})$ and the 1952 Tokachi earthquake $(54 \mathrm{~cm})$. This means that the strongest non-seismic seiches at this station for the observation period (1947-1956) were $<54 \mathrm{~cm}$

- Typhoons Lionrock (2016) and Jebi (2018) and associated extreme seiches/meteotsunamis should be regarded as exceptional events; maximum seiche heights at three stations were substantially higher than 10-20-year historical maxima, and two more stations they were of the same order.

It is interesting to compare maximum wave heights recorded during the 2016 and 2018 events with historical maxima for all stations and records examined by Nakano and Unoki (1962). Our data are related to only two specific events, while the historical data presented in that study are based on analysis of 45 stations with continuous sea level observations from 8 to 27 years (between 1930 and 1956). The pivot Table 5 includes all events of atmospheric origin with wave heights more than $120 \mathrm{~cm}$. The maximum wave heights listed by Nakano and Unoki (1962), 169 and $156 \mathrm{~cm}$, were recorded at station Mera located at the southernmost end of the Boso Peninsula approximately $90 \mathrm{~km}$ south from Tokyo. Both events (1943 and 1939) were associated with propagating typhoons. Two strong events $(145$ and $140 \mathrm{~cm})$, initiated by a travelling anticyclone and low-pressure system over the Sea of Japan, respectively, were observed at Miyako (north-eastern coast of Honshu Island, see Fig. 1). Intense seiches with a wave height of $143 \mathrm{~cm}$ at Kushimoto were generated by typhoon Agnes (1952).

These were the five strongest events listed in Nakano and Unoki's table. However, both 257-cm seiches at Gobo induced by typhoon Jebi (2018) and 171-cm seiches at Erimo caused by typhoon Lionrock were stronger than these five historical events and all other events described by Nakano and Unoki (1962). Moreover, wave heights of $138 \mathrm{~cm}$ at Kushimoto and $137 \mathrm{~cm}$ at Kumano, both initiated by typhoon Jebi, are in Lines 8 and 9 in our table (Table 5). All these clearly demonstrate that typhoons Lionrock and Jebi, 


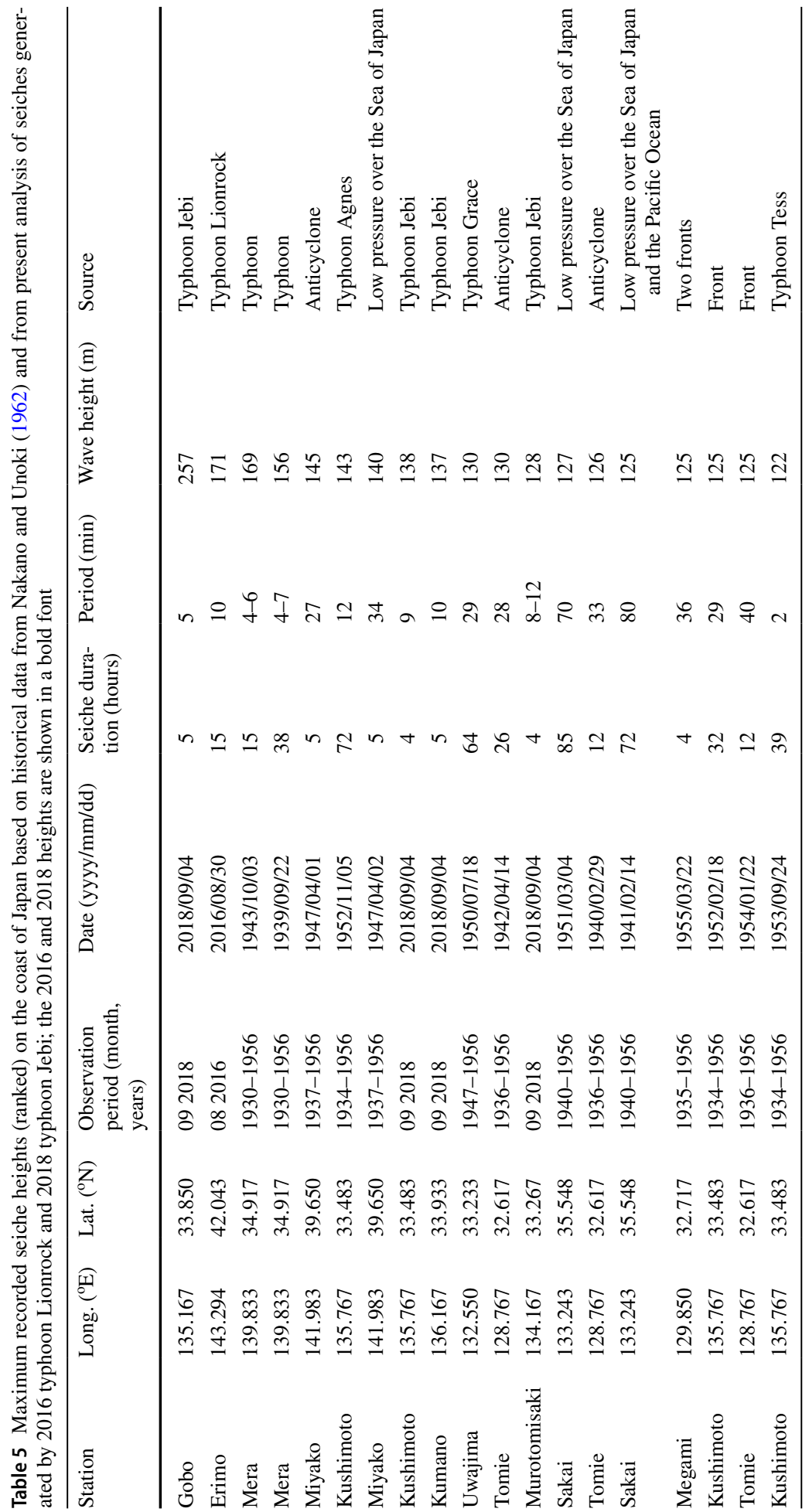


especially the second one, were extraordinary events. Also we assume that sites listed in Table 5, in particular, Gobo, Erimo, Mera, Miayko, Kushimoto, Kumano, Sakai, etc., may be considered as "hot spots" for the coast of Japan; it appears that strong, atmospherically generated seiches, i.e. meteotsunamis, are a specific feature of these sites. The data presented in Table 5 show that seiches/meteotsunamis generated by typhoons affecting Japan are much stronger than those caused by hurricanes propagating along or across the East USA Coast and the Gulf of Mexico (Olabarrieta et al. 2017; Dusek et al. 2019). Thus, the results of analysis of 22-yr data records at 125 stations on the North-east, mid-Atlantic, South-east and Caribbean coasts of the USA indicated that the largest recorded meteotsunamis were: a 1.19-m event at Port Canaveral (Florida) on 19 June 1996 and a 1.04-m event at Providence (Rhode Island) during a winter storm on 9 December 2005 (Dusek et al. 2019). Both Providence and Port Canaveral had multiple large events exceeding a wave height of $0.6 \mathrm{~m}$, but very few exceeding $0.8 \mathrm{~m}$. The 50 -yr return periods suggest $1.26 \mathrm{~m}$ at Port Canaveral, $1.12 \mathrm{~m}$ at Woods Hole and 0.97 at Providence; at all other sites the predicted 50-yr heights are significantly smaller. The reason for this difference is not clear: Either typhoons affecting the main coast of Japan are stronger than hurricanes impacting the Atlantic coast of the USA, or the local topographic conditions on the Japanese coast are more favourable to produce strong highfrequency sea level oscillations than those on the East Coast of the USA.

It is interesting that some of the events listed in Table 5, in particular Miyako, 1947 $(145 \mathrm{~cm})$; Tomie, $1942(130 \mathrm{~cm})$ and $1940(126 \mathrm{~cm})$, occurred during anticyclones, i.e. when there were a high pressure and good weather. It is evident that the corresponding seiches had a principally different generation mechanism than those generated by hurricanes, but probably similar to the extreme seiches typical for the Mediterranean Sea (cf. Šepić et al. 2015) and may be considered as "good weather meteotsunamis" (Rabinovich 2020).

It should be emphasized that the information from Nakano and Unoki (1962) presented in Table 5 stops on 1956. Between 1956 and 2016, i.e. in 60 years, there were probably about 150 typhoons affecting the coasts of Japan including such catastrophic typhoons as Typhoon Vera, also known as "Isewan Typhoon" (September 1959), that killed over 5000 people and produced a $3.9 \mathrm{~m}$ surge in the Port of Nagoya (https://wiki2 .org/en/Typhoon_Vera). So, these statistics have to be considered as very preliminary. Nevertheless, it gives some important information about the character of atmospherically induced seiches in this region and helps to specify some hot spots.

The Gobo event on 4 September 2018, with a maximum recorded wave height of $257 \mathrm{~cm}$ (Table 5), appears to be one of the strongest recorded meteotsunamis generated by a typhoon or hurricane. Moreover, recently Gusiakov (2020) prepared a list of the 20 largest validated meteotsunamis observed in the world in 1978-2020 and that list includes the Gobo event (as No. 20). Certainly, such events as Gobo can produce severe damage to boats and port infrastructure, as well as a serious threat to human lives.

\section{Conclusions}

Two devastating typhoons, Lionrock in August 2016 and Jebi in September 2018, destructively affected the eastern coast of Japan and produced extreme sea level variations and coastal floods. The field surveys in the impacted regions showed that the multiple deaths and extensive floods in these regions were caused by the combined effect of low-frequency 
sea level rise (storm surges) and intensive high-frequency tsunami-like seiches (meteotsunamis). In the present study, we used the data from ten coastal tide gauges for the 2016 event and eight tide gauges for the 2018 event to examine the properties of the sea level oscillations in the affected regions, to estimate the relative contribution of these two sea level components and to evaluate their statistical characteristics. Our main findings are the following:

- For the 2016 event, we found that the surge heights were from $12 \mathrm{~cm}$ (Hanasaki) to $35 \mathrm{~cm}$ (Erimo and Hakodate); the mean contribution of the storm surge into the total observed sea level heights was $\sim 39 \%$; the seiche/meteotsunami amplitudes were from $22 \mathrm{~cm}$ (Hanasaki) to $92 \mathrm{~cm}$ (Erimo), and they contributed $\sim 61 \%$ of the total height.

- For the 2018 event, storm surges were significantly stronger, from $46 \mathrm{~cm}$ (Kumano) to $170 \mathrm{~cm}$ (Gobo), while seiche amplitudes were from $38 \mathrm{~cm}$ (Komatsujima) to $130 \mathrm{~cm}$ (Gobo); their mean relative inputs were $67 \%$ and $33 \%$, respectively.

- The contribution of storm seiches in coastal floods had previously been underestimated, but results of the present study demonstrate that they can play the principal role. Combined together, the surge and tsunami-like seiches create prominent damaging effects. During the 2016 event, the maximum total flood height of $120 \mathrm{~cm}$ was at Erimo. The cumulative effect of surge and seiches (meteotsunamis) was exceptionally strong during the 2018 event: the maximum recorded surge + seiche wave heights were $288 \mathrm{~cm}$ at Gobo and $178 \mathrm{~cm}$ at Murotomisaki; at the other six stations examined they were also high-from 99 to $135 \mathrm{~cm}$.

- What is especially important, the extreme currents that produce severe damage to port facilities, anchored boats and coastal infrastructure, are specifically associated with the storm seiches/meteotsunamis. Our rough estimates indicate that the current speeds during the Lionrock event were up to 3 knots and during Jebi were more than 5 knots.

- The most important characteristic of recorded meteotsunamis is their trough-to-crest heights. During the 2016 event these heights at three stations were $>1 \mathrm{~m}: 171 \mathrm{~cm}$ at Erimo, $109 \mathrm{~cm}$ at Hachijojima and $102 \mathrm{~cm}$ at Ayukawa. The 2018 event was stronger; maximum meteotsunami wave heights were $257 \mathrm{~cm}$ at Gobo, $138 \mathrm{~cm}$ at Kushimoto, $137 \mathrm{~cm}$ at Kumano and $128 \mathrm{~cm}$ at Murotomisaki. The 2018 Gobo height of $257 \mathrm{~cm}$ is much larger than historical non-seismic seiche maxima of 140-169 cm for the Pacific coast of Japan estimated by Nakano and Unoki (1962) based on analysis of 10-27-year records from 45 stations located on this coast. The recorded 2016 and 2018 meteotsunami heights were also much larger than maximum heights of hurricane-generated meteotsunamis of $119 \mathrm{~cm}$ (Port Canaveral, Florida) and $104 \mathrm{~cm}$ (Providence, Rhode Island) estimated by Dusek et al. (2019) based on analysis of 22-yr data records at 125 stations along the Atlantic coast of the USA.

Acknowledgements We are grateful to Dr Hiroshi Takagi (Tokyo Institute of Technology, Japan), Mr Takumu Iwamoto (Port and Airport Research Institute, Yokosuka, Japan) and Dr Tomohiro Takagawa (Port and Airport Research Institute, Yokosuka, Japan) for assisting us during the field surveys of the coastal damage from two typhoons examined in this article. We thank Takumu Iwamoto for providing us with the air pressure measurements reported in this study. Tide gauge data were provided by the Japan Meteorological Agency (JMA) through Toshihiro Ueno (JMA, Sapporo District Meteorological Observatory, Japan) and Shigeki Nakagawa and Professor Kenji Satake (both from the University of Tokyo, Japan). The authors gratefully acknowledge Fred Stephenson (Institute of Ocean Sciences, Sidney, BC, Canada) for valuable comments and suggestions. We used the GMT software for drafting some of the figures (Wessel and Smith 1998). For AR, this work was partially supported by the Russian State Assignment of IORAS \#0149-20190005. MH was funded by the Royal Society, the UK, grant number CHL/R1/180173. 


\section{Compliance with ethical standards}

Conflict of interest The authors declare that they have no competing interests. The data and material used in this research are partly available in the body of the article; other data/material is also available to public and will be provided through writing to the corresponding author.

Open Access This article is licensed under a Creative Commons Attribution 4.0 International License, which permits use, sharing, adaptation, distribution and reproduction in any medium or format, as long as you give appropriate credit to the original author(s) and the source, provide a link to the Creative Commons licence, and indicate if changes were made. The images or other third party material in this article are included in the article's Creative Commons licence, unless indicated otherwise in a credit line to the material. If material is not included in the article's Creative Commons licence and your intended use is not permitted by statutory regulation or exceeds the permitted use, you will need to obtain permission directly from the copyright holder. To view a copy of this licence, visit http://creativecommons.org/licenses/by/4.0/.

\section{References}

Admire AR, Dengler LA, Crawford GB, Uslu BU, Borrero JC, Greer SD, Wilson RI (2014) Observed and modeled currents from the Tohoku-oki, Japan and other recent tsunamis in northern California. Pure Appl Geophys 171(12):3385-3403

Bajo M, Medugorac I, Umgiesser G, Orlić M (2019) Storm surge and seiche modelling in the Adriatic Sea and the impact of data assimilation. Q J R Meteorol Soc 145:2070-2084. https://doi. org/10.1002/qj.3544

Borrero JC, Lynett PJ, Kalligeris N (2015) Tsunami currents in ports. Phil Trans R Soc A373(2053):20140372

De Jong MPC, Holthuijsen LH, Battjes JA (2003) Generation of seiches by cold fronts over the southern North Sea. J Geophys Res 108(C4):3117. https://doi.org/10.1029/2002JC001422

Dengler L, Uslu B, Barberopoulou A, Borrero J, Synolakis C (2008) The vulnerability of Crescent City, California, to tsunamis generated by earthquakes in the Kuril Islands region of the northwestern Pacific. Seismol Res Lett 79(5):608-619

Dusek G, DiVeglio C, Licate L, Heilman L, Kirk K, Paternostro C, Miller A (2019) A meteotsunami climatology along the U.S. East Coast. Bull Am Meteorol Soc 100(7):1329-1345. https://doi. org/10.1175/BAMS-D-18-0206.1

FDMA, Fire and Disaster Management Agency (2017) Damages caused by Typhoon 1610 (Report no. 43). https://www.fdma.go.jp/disaster/info/assets/post816.pdf

FDMA, Fire and Disaster Management Agency (2018) Damages by Typhoon No. 21 in 2018 and the response of fire and disaster management agency. http://www.fdma.go.jp/bn/5088fc7540585e7 232370c8db10e55e8b1c909ae.pdf.Accessed 19 Jan 2019

Gomis D, Monserrat S, Tintoré J (1993) Pressure-forced seiches of large amplitude in inlets of the Balearic Islands. J Geophys Res 98:14437-14445

Gusiakov VK (2020) Meteotsunamis at global scale: problems of event identification, parameterization and cataloguing. Natural Hazards. https://doi.org/10.1007/s11069-020-04230-2

Heidarzadeh M, Necmioglu O, Ishibe T, Yalciner AC (2017) Bodrum-Kos (Turkey-Greece) Mw 6.6 earthquake and tsunami of 20 July 2017: a test for the Mediterranean tsunami warning system. Geosci Lett 4:31. https://doi.org/10.1186/s40562-017-0097-0

Heidarzadeh M, Teeuw R, Day S, Solana C (2018) Storm wave runups and sea level variations for the September 2017 Hurricane Maria along the coast of Dominica, eastern Caribbean Sea: evidence from field surveys and sea level data analysis. Coastal Eng J 60(3):371-384. https://doi. org/10.1080/21664250.2018.1546269

Heidarzadeh M, Šepić J, Rabinovich A, Allahyar M, Soltanpour A, Tavakoli F (2020a) Meteorological tsunami of 19 March 2017 in the Persian Gulf: observations and analyses. Pure Appl Geophys 177:1231-1259. https://doi.org/10.1007/s00024-019-02263-8

Heidarzadeh M, Iwamoto T, Takagawa T, Takagi H (2020b) Field surveys and numerical modeling of the August 2016 typhoon Lionrock along the northeastern coast of Japan: the first typhoon making landfall in Tohoku region. Nat Hazards. https://doi.org/10.1007/s11069-020-04112-7 
Heidarzadeh M, Ishibe T, Sandanbata O, Muhari A, Wijanarto AB (2020c) Numerical modeling of the subaerial landslide source of the 22 December 2018 Anak Krakatoa volcanic tsunami, Indonesia. Ocean Eng 195:106733

Hibiya T, Kajiura K (1982) Origin of 'Abiki' phenomenon (kind of seiches) in Nagasaki Bay. J Oceanogr Soc Japan 38:172-182

Honda K, Terada T, Yoshida Y, Isitani D (1908) An investigation on the secondary undulations of oceanic tides. J Coll Sci Imp Univ Tokyo 24:1-110

Horikawa K (1961) Tsunami phenomena in the light of engineering view-point. Report on the Chilean tsunami of May 24, 1960, as observed along the coast of Japan. Tokyo, Japan: University of Tokyo

Inazu D, Ikeya T, Waseda T, Hibiya T, Shigihara Y (2018) Measuring offshore tsunami currents using ship navigation records. Prog Earth Planet Sci 5(1):38

Le TA, Takagi H, Heidarzadeh M, Takata Y, Takahashi A (2019) Field surveys and numerical simulation of the 2018 Typhoon Jebi: impact of high waves and storm surge in semi-enclosed Osaka Bay, Japan. Pure Appl Geophys 176(10):4139-4160. https://doi.org/10.1007/s00024-019-02295-0

Linares Á, Wu CH, Bechle AJ, Anderson EJ, Kristovich DAR (2019) Unexpected rip currents induced by a meteotsunami. Sci Rep 9(2015). https://doi.org/10.1038/s41598-019-38716-2

Lynett PJ, Borrero JC, Weiss R, Son S, Greer D, Renteria W (2012) Observations and modeling of tsunami-induced currents in ports and harbors. Earth Planet Sci Lett 327:68-74. https://doi.org/10.1016/j. eps1.2012.02.002

Lynett PJ, Borrero J, Son S, Wilson R, Miller K (2014) Assessment of the tsunami-induced current hazard. Geophys Res Lett 41(6):2048-2055. https://doi.org/10.1002/2013GL058680

Mitsuta Y, Yoshizumi S (1968) Characteristics of the second Miyakojima typhoon. Bull Dims Prey. Res Inst, Kyoto Univ 131:15-34

Monserrat S, Thorpe AJ (1996) Use of ducting theory in an observed case of gravity waves. J Atmos Sci 53(12):1724-1736

Monserrat S, Ibberson A, Thorpe AJ (1991) Atmospheric gravity waves and the "rissaga" phenomenon. Q J R Meteorol Soc 117:553-570

Monserrat S, Vilibić I, Rabinovich AB (2006) Meteotsunamis: atmospherically induced destructive ocean waves in the tsunami frequency band. Nat Hazards Earth Sys Sci 6:1035-1051

Mori N, Yasuda T, Arikawa T, Kataoka T, Nakajo S, Suzuki K (2019) 2018 Typhoon Jebi post-event survey of coastal damage in the Kansai region. Japan Coast Eng J 61(3):278-294

Nakano M, Unoki S (1962) On the seiches (secondary undulations of tides) along the coast of Japan Records Oceanogr. Works Japan, Spec 6:169-214

Nayak S, Takemi T (2019) Dynamical downscaling of Typhoon Lionrock (2016) for assessing the resulting hazards under global warming. Ser. II, J Meteor Soc Japan. https://doi.org/10.2151/jmsj.2019-003

Nomitsu T (1935) A theory of tsunamis and seiches produced by wind and barometric gradient. Memoirs of the College of Science; Kyoto Imperial University. Series A 18:201-214

Olabarrieta M, Valle-Levinson A, Martinez CJ, Pattiaratchi C, Shi L (2017) Meteotsunamis in the northeastern Gulf of Mexico and their possible link to El Niño Southern oscillation. Nat Hazards 88:13251346. https://doi.org/10.1007/s11069-017-2922-3

Orlić M, Belušić D, Janeković I, Pasarić M (2010) Fresh evidence relating the great Adriatic surge of 21 June 1978 to mesoscale atmospheric forcing. J Geophys Res 115:C06011. https://doi.org/10.1029/2009J $\mathrm{C} 005777$

Pasquet S, Vilibić I, Šepić J (2013) A survey of strong high-frequency sea level oscillations along the US East Coast between 2006 and 2011. Nat Hazards Earth Sys Sci 13:473-482. https://doi.org/10.5194/ nhess-13-473-2013

Pattiaratchi CB, Wijeratne EMS (2015) Are meteotsunamis an underrated hazard? Phil Trans R SocA 373(20140377):1-23

Pawlowicz R, Beardsley B, Lentz S (2002) Classical tidal harmonic analysis including error estimates in MATLAB using T_TIDE". Comput Geosci 28:929-937

Pugh D, Woodworth P (2014) Sea-level science: understanding tides, surges tsunamis and mean sea-level changes. Uni. Press, Cambridge, p 395

Rabinovich AB (2009) Seiches and harbor oscillations. In: Kim YC (ed) Handbook of coastal and ocean engineering. World Scientific Publ, Singapore, pp 193-236

Rabinovich AB (2020) Twenty-seven years of progress in the science of meteorological tsunamis following the 1992 Daytona Beach event. Pure Appl Geophys 177(3):1193-1230. https://doi.org/10.1007/s0002 4-019-02349-3

Rabinovich AB, Monserrat S (1996) Meteorological tsunamis near the Balearic and Kuril Islands: descriptive and statistical analysis. Nat Hazards 13:55-90 
Rabinovich AB, Monserrat S (1998) Generation of meteorological tsunamis (large amplitude seiches) near the Balearic and Kuril Islands. Nat Hazards 18:27-55

Rabinovich AB, Šepić J, and Thomson, RE (2020), The meteorological tsunami of 1 November 2010 in the southern Strait of Georgia: a case study. Natural Hazards. https://doi.org/10.1007/s11069-020-04203-5

Roeber V, Bricker JD (2015) Destructive tsunami-like wave generated by surf beat over a coral reef during Typhoon Haiyan. Nat Commun 6(7854). https://doi.org/10.1038/ncomms8854

Salaree A, Mansouri R, Okal EA (2018) The intriguing tsunami of 19 March 2017 at Bandar Dayyer, Iran: field survey and simulations. Nat Hazards 90(3):1277-1307. https://doi.org/10.1007/s1106 9-017-3119-5

Šepić J, Rabinovich AB (2014) Meteotsunami in the Great Lakes and on the Atlantic coast of the United States generated by the "derecho" of June 29-30, 2012. Nat Hazards 74:75-107. https://doi. org/10.1007/s11069-014-1310-5

Šepić J, Vilibić I, Rabinovich AB, Monserrat S (2015) Widespread tsunami-like waves of 23-27 June in the Mediterranean and black seas generated by high-altitude atmospheric forcing. Scientific Rep 5(11682):1-5. https://doi.org/10.1038/srep11682

Sorensen RM (2010) Basic coastal engineering, 3rd edn. Springer, Berlin, p 324

Takabatake T, Mall M, Esteban M, Nakamura R, Kyaw TO, Ishii H et al (2018) Field survey of 2018 Typhoon Jebi in Japan: lessons for disaster risk management. Geosciences 8:412. https://doi. org/10.3390/geosciences8110412

Tanaka K (2010) Atmospheric pressure-wave bands around a cold front resulted in a meteotsunami in the East China Sea in February 2009. Nat Hazards Earth Sys Sci 10(12):2599-2610

Tanaka K (2019) Meteotsunamis propagating along continental slope in the northwestern Pacific Ocean: a case study of the January 2018 event in Shikoku area, The First World Conference on Meteotsunamis, Split, Croatia, 8-11 May 2019, Book of Abstracts, p. 35

Thomson RE, Emery WJ (2014) Data Analysis Methods in Physical Oceanography. Elsevier, Amsterdam, p 634

Thomson RE, Rabinovich AB, Krassovski MV (2007) Double jeopardy: concurrent arrival of the 2004 Sumatra tsunami and storm-generated waves on the Atlantic coast of the United States and Canada. Geophys Res Lett 34:L15607. https://doi.org/10.1029/2007GL030685

Thomson RE, Rabinovich AB, Fine IV et al (2009) Meteorological tsunamis on the coasts of the British Columbia and Washington. Phys Chem Earth 34:971-988

Vilibić I, Šepić J (2009) Destructive meteotsunamis along the eastern Adriatic coast: overview. Phys Chem Earth 34:904-917. https://doi.org/10.1016/j.pce.2009.08.004

Vilibić I, Domijan N, Orlic M, Leder N, Pasaric M (2004) Resonant coupling of a traveling air pressure disturbance with the east Adriatic coastal waters. J Geophys Res 109:C10001. https://doi. org/10.1029/2004JC002279

Vilibić I, Monserrat S, Rabinovich AB (2014) Meteorological tsunamis on the US East Coast and in other regions of the World Ocean. Nat Hazards 74(1):1-9. https://doi.org/10.1007/s11069-014-1350-X

Vilibić I, Šepić J, Rabinovich AB, Monserrat S (2016) Modern approaches in meteotsunami research and early warning. Front Marine Sci 3(57):1-7. https://doi.org/10.3389/fmars.2016.00057

Wessel P, Smith WHF (1998) New, improved version of generic mapping tools released. Eos Trans AGU 79(47):579. https://doi.org/10.1029/98EO00426

Wilson RI, Admire AR, Borrero JC et al (2013) Observations and impacts from the 2010 Chilean and 2011 Japanese tsunamis in California (USA). Pure Appl Geophys 170(6-8):1127-1147

Publisher's Note Springer Nature remains neutral with regard to jurisdictional claims in published maps and institutional affiliations.

\section{Affiliations}

\section{Mohammad Heidarzadeh $^{1}$ (D) Alexander B. Rabinovich ${ }^{2,3}$}

Mohammad Heidarzadeh

mohammad.heidarzadeh@brunel.ac.uk

https://www.brunel.ac.uk/people/mohammad-heidarzadeh

1 Department of Civil and Environmental Engineering, Brunel University London,

Uxbridge UB8 3PH, UK 
2 Institute of Ocean Sciences, Fisheries and Oceans Canada, Sidney, BC V8L 4B2, Canada

3 Shirshov Institute of Oceanology, Russian Academy of Sciences, Moscow, Russia 117993 